\title{
Evaluating Integration of Inland Bathymetry in the U.S. Geological Survey 3D Elevation Program, 2014
}

Open-File Report 2016-1126 



\section{Evaluating Integration of Inland Bathymetry in the U.S. Geological Survey 3D Elevation Program, 2014}

By Cynthia Miller-Corbett

Open-File Report 2016-1126 


\title{
U.S. Department of the Interior SALLY JEWELL, Secretary
}

\section{U.S. Geological Survey Suzette M. Kimball, Director}

\author{
U.S. Geological Survey, Reston, Virginia: 2016
}

For more information on the USGS - the Federal source for science about the Earth, its natural and living resources, natural hazards, and the environment—visit http://www.usgs.gov or call 1-888-ASK-USGS.

For an overview of USGS information products, including maps, imagery, and publications, visit http://store.usgs.gov.

Any use of trade, firm, or product names is for descriptive purposes only and does not imply endorsement by the U.S. Government.

Although this information product, for the most part, is in the public domain, it also may contain copyrighted materials as noted in the text. Permission to reproduce copyrighted items must be secured from the copyright owner.

Suggested citation:

Miller-Corbett, Cynthia, 2016, Evaluating integration of inland bathymetry in the U.S. Geological Survey 3D Elevation Program, 2014: U.S. Geological Survey Open-File Report 2016-1126, 44 p., http://dx.doi.org/10.3133/ofr20161126.

ISSN 2331-1258 (online) 


\section{Contents}

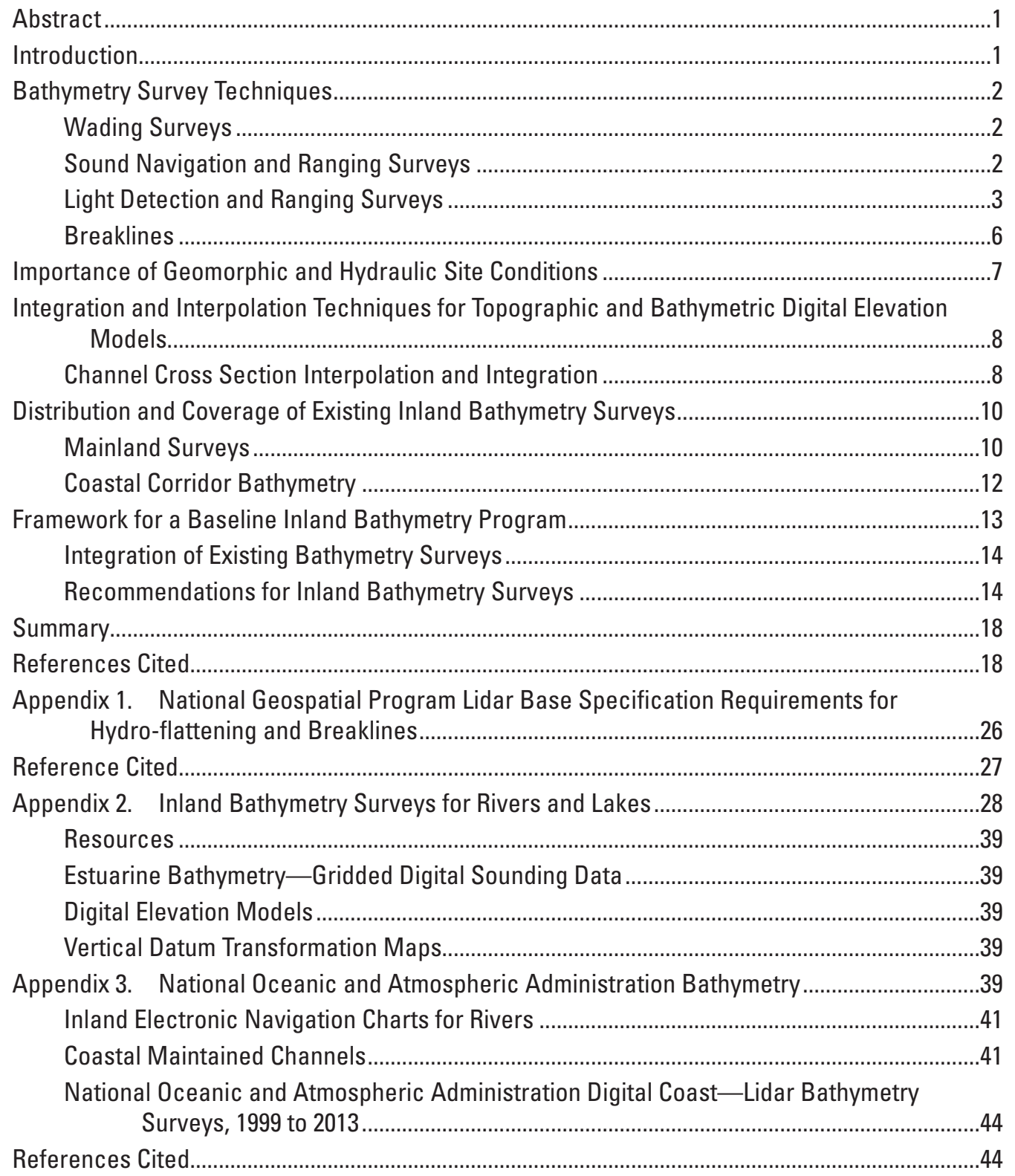




\section{Figures}

1. Map showing upper Mississippi River System completed pool bathymetric surveys

2. Map showing distribution of collected inland bathymetry surveys for the conterminous United States and Alaska

3. Map showing distribution of primary river systems for the conterminous United States and Alaska,

4. Illustration showing total freshwater withdrawals and projected domestic water use

\section{Appendix Figures}

3-1. Screen capture showing orthwest Pacific Coastal Relief Model

3-2. Map showing National Oceanic and Atmospheric Administration vertical datum transformation tool for the Gulf of Mexico.

3-3. Screen capture showing Inland Electronic Navigation Chart.

3-4. Map showing U.S. Army Corps of Engineers maintained channels

\section{Tables}

1. Light detection and ranging specifications for The National Map (Heidemann, 2014) ....4

2. Light detection and ranging bathymetry survey parameters.

3. Light detection and ranging results from different river bed mediums ............................6

4. Root mean square error Cartesian and channel-fitted coordinate system statistics for interpolation techniques.........................................................................................

5. Acoustic inland bathymetric surveys for lakes and rivers ............................................10

6. Light detection and ranging for inland bathymetric river surveys ..................................11

7. Combined techniques for inland bathymetry lake and river surveys .............................11

8. Acoustic, light detection and ranging, and combined inland bathymetry survey coverages for lakes and rivers

\section{Appendix Tables}

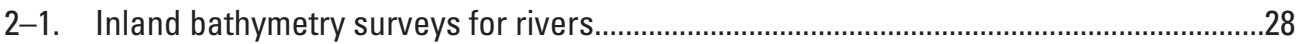

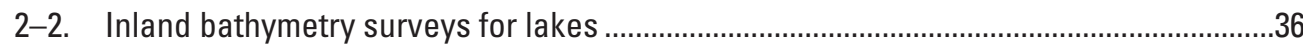

3-1. U.S. Army Corps of Engineers Inland Electronic Navigation Charts-River Surveys ....42 


\section{Conversion Factors}

[U.S. customary units to International System of Units]

\begin{tabular}{lcl}
\hline & Multiply & \multicolumn{1}{c}{ To obtain } \\
\hline foot (ft) & Length & \\
foot (ft) & 30.48 & centimeter $(\mathrm{cm})$ \\
mile (mi) & 0.3048 & meter $(\mathrm{m})$ \\
mile, nautical (nmi) & 1.609 & kilometer $(\mathrm{km})$ \\
yard (yd) & 1.852 & kilometer $(\mathrm{km})$ \\
& 0.9144 & meter $(\mathrm{m})$ \\
\hline square foot $\left(\mathrm{ft}^{2}\right)$ & Area & \\
acre & 0.09290 & square meter $\left(\mathrm{m}^{2}\right)$ \\
square mile $\left(\mathrm{mi}^{2}\right)$ & 4,047 & square meter $\left(\mathrm{m}^{2}\right)$ \\
\hline
\end{tabular}

[International System of Units to U.S. customary units]

\begin{tabular}{lcl}
\hline \multicolumn{1}{c}{ Multiply } & By & \multicolumn{1}{c}{ To obtain } \\
\hline centimeter $(\mathrm{cm})$ & Length & foot (ft) \\
meter $(\mathrm{m})$ & 0.032 & foot (ft) \\
kilometer $(\mathrm{km})$ & 3.281 & mile (mi) \\
kilometer $(\mathrm{km})$ & 0.6214 & mile, nautical (nmi) \\
meter $(\mathrm{m})$ & 0.5400 & yard (yd) \\
\hline & 1.094 & \\
\hline square meter $\left(\mathrm{m}^{2}\right)$ & Area & square foot $\left(\mathrm{ft}^{2}\right)$ \\
square meter $\left(\mathrm{m}^{2}\right)$ & 10.76 & acre \\
square kilometer $\left(\mathrm{km}^{2}\right)$ & 0.0002471 & square mile $\left(\mathrm{mi}^{2}\right)$ \\
\hline
\end{tabular}

Temperature in degrees Celsius $\left({ }^{\circ} \mathrm{C}\right)$ may be converted to degrees Fahrenheit $\left({ }^{\circ} \mathrm{F}\right)$ as ${ }^{\circ} \mathrm{F}=\left(1.8 \times{ }^{\circ} \mathrm{C}\right)+32$.

Temperature in degrees Fahrenheit $\left({ }^{\circ} \mathrm{F}\right)$ may be converted to degrees Celsius $\left({ }^{\circ} \mathrm{C}\right)$ as ${ }^{\circ} \mathrm{C}=\left({ }^{\circ} \mathrm{F}-32\right) / 1.8$.

\section{Datum}

Vertical coordinate information is referenced to the North American Vertical Datum of 1988 (NAVD 88).

Horizontal coordinate information is referenced to the North American Datum of 1983 (NAD 83). 


\section{Abbreviations}

$\begin{array}{ll}\text { 3D } & \text { three-dimensional } \\ \text { 3DEP } & \text { 3D Elevation Program } \\ \text { ADCP } & \text { acoustic Doppler current profiler } \\ \text { ALB } & \text { airborne lidar bathymetry } \\ \text { CZMIL } & \text { Coastal Zone Mapping and Imaging Lidar } \\ \text { CoNED } & \text { Coastal National Elevation Dataset } \\ \text { DEM } & \text { digital elevation model } \\ \text { EAARL } & \text { Experimental Advanced Airborne Research Lidar } \\ \text { EPA } & \text { U.S. Environmental Protection Agency } \\ \text { FHWA } & \text { Federal Highway Administration } \\ \text { HEC-RAS } & \text { Hydrologic Engineering Center-River Analysis System } \\ \text { GPS } & \text { global positioning system } \\ \text { IHO } & \text { International Hydrographic Organization } \\ \text { LADS } & \text { Laser Airborne Depth Sounder } \\ \text { lidar } & \text { light detection and ranging } \\ \text { NGP } & \text { National Geospatial Program } \\ \text { NOAA } & \text { National Oceanic and Atmospheric Administration } \\ \text { NTU } & \text { Nephelometric Turbidity Units } \\ \text { SHOALS } & \text { Scanning Hydrographic Operational Airborne Lidar System } \\ \text { SOnar } & \text { sound navigation and ranging } \\ \text { RMSE } & \text { root mean square error } \\ \text { USK } & \text { real time kinematic } \\ \text { USGS } & \text { U.S. Army Corps of Engineers } \\ \text { U. Geological Survey }\end{array}$




\title{
Evaluating Integration of Inland Bathymetry in the U.S. Geological Survey 3D Elevation Program, 2014
}

\author{
By Cynthia Miller-Corbett
}

\section{Abstract}

Inland bathymetry survey collections, survey data types, features, sources, availability, and the effort required to integrate inland bathymetric data into the U.S. Geological Survey 3D Elevation Program are assessed to help determine the feasibility of integrating three-dimensional water feature elevation data into The National Map. Available data from wading, acoustic, light detection and ranging, and combined technique surveys are provided by the U.S. Geological Survey, National Oceanic and Atmospheric Administration, U.S. Army Corps of Engineers, and other sources. Inland bathymetric data accessed through Web-hosted resources or contacts provide useful baseline parameters for evaluating survey types and techniques used for collection and processing, and serve as a basis for comparing survey methods and the quality of results. Historically, boat-mounted acoustic surveys have provided most inland bathymetry data. Light detection and ranging techniques that are beneficial in areas hard to reach by boat, that can collect dense data in shallow water to provide comprehensive coverage, and that can be cost effective for surveying large areas with good water clarity are becoming more common; however, optimal conditions and techniques for collecting and processing light detection and ranging inland bathymetry surveys are not yet well defined.

Assessment of site condition parameters important for understanding inland bathymetry survey issues and results, and an evaluation of existing inland bathymetry survey coverage are proposed as steps to develop criteria for implementing a useful and successful inland bathymetry survey plan in the 3D Elevation Program. These survey parameters would also serve as input for an inland bathymetry survey data baseline. Integration and interpolation techniques are important factors to consider in developing a robust plan; however, available survey data are usually in a triangulated irregular network format or other format compatible with the 3D Elevation Program so that data can be integrated with a minimal level of effort. Geomorphic site conditions are known to affect the success and accuracy of light detection and ranging and other bathymetric surveys, and a baseline that includes geomorphic data is recommended to help in evaluation of limitations imposed by geomorphology for surveys completed in the variable physiographic provinces across the United States.
The geographic distribution for existing surveys identifies regions where inland bathymetry data have been collected and, conversely, where little or no survey data seem to be available to provide hydrologic and hydraulic information. This distribution, in conjunction with local to regional data needs to characterize and monitor river and lake resources, provides another important set of criteria to propose and guide acquisition of new bathymetry data for the 3D Elevation Program. An initial evaluation of needs can be based on the importance of water resources that provide primary water supplies for communities, agriculture, energy, and ecological systems; the importance of flood plain analyses; and projected population growth across the United States.

\section{Introduction}

An assessment of inland bathymetric and topographic bathymetry survey methods and products for projects with data that are or can be made available to the U.S. Geological Survey (USGS), and proposed criteria for implementing an inland bathymetry database in the 3D Elevation Program (3DEP) are presented. Bathymetry is a measurement of water depth used to derive bottom surface elevations for stream/ river (river) and lake/pond (waterbody) features. In the same way that topographic maps represent the three-dimensional (3D) features of overland terrain, bathymetric maps depict 3D channel and lake geometries important to hydrologic and hydraulic analyses and modeling. Topographic bathymetry (referred to herein as "topobathymetry") is an elevation data product derived by merging topography and bathymetry. Originally developed to map ocean coastlines and seafloors for navigational charting, bathymetric mapping is now recognized as important in analyses and modeling critical to evaluating, planning use or development, and for protecting water supplies. Bathymetry surveys are also important in flood plain analysis and modeling.

Existing, available bathymetric and topobathymetric datasets that the USGS could acquire are described. An overview of wading, acoustic, and light detection and ranging (lidar) bathymetric survey parameters, advantages, and disadvantages provides background for understanding the best methods and practices for river or waterbody surveys. Tallied 
survey parameters include survey locations and coverage, survey techniques, and some data development methods. Data formatting and interpolation or integration techniques are also described. Most of the compiled inland bathymetric surveys are completed by the USGS; however, in the coastal corridor including deltaic to intertidal and offshore zones and the Great Lakes, the U.S. Army Corps of Engineers (USACE) and the National Oceanic and Atmospheric Administration (NOAA) collect and provide the bulk of bathymetry data.

Lidar surveys are known to provide high accuracy data for topographic digital elevation or terrain models (Hohenthal and others, 2011); h owever, lidar inland bathymetry surveys present new challenges, and a more complete assessment of suitable conditions and processing algorithms is needed to foster the best use of resources and to develop quality bathymetric data. To develop lidar survey guidance and determine appropriate processing solutions, pilot surveys are recommended for sites under variable conditions to assess survey success or problems that can be correlated to bed mediums, bank slopes, flood and drought attributes, shape (straight versus meandering), depths, and other features that characterize physiographic regions across the United States. These survey parameters would be included in an inland bathymetry survey baseline as a valuable resource to determine best practices for completing lidar-derived inland bathymetry projects under variable conditions. This approach aligns with goals for modernizing and providing a wide range of information products to meet the National Geospatial Program communities of use (Stoker and others, 2013).

\section{Bathymetry Survey Techniques}

Inland bathymetry surveys are completed using wading, acoustic, or remote-sensing survey techniques. In some cases, a combination of these techniques is required to create bathymetric cross sections and profiles. In 2009, surveys using a global positioning system (GPS), total station, or leveling instruments were still the standard for stream mapping (McKean and others, 2009) and still are important for stream surveys. In 2011, sound navigation and ranging (sonar) systems were used more than any other tool to create bathymetry data (Hohenthal and others, 2011). Lidar systems using green waveform signals have become standard for shallowwater coastal settings. Because experience has indicated that airborne lidar surveys can quickly cover large areas when compared to wading or acoustic surveys and provide highly accurate depth data, these systems are becoming the technique of choice where conditions are appropriate.

\section{Wading Surveys}

Wading surveys measure water depths using stadia rod or weighted-tape measures and commonly locate survey points using real-time kinematic (RTK-GPS) equipment.
Disadvantages of wading surveys are that they can be slow, labor intensive, costly, and often are done with point measurements spaced more than 1 meter apart in at least one dimension, producing digital elevation models (DEMs) with a fairly coarse spatial resolution. Also, because each point elevation measurement takes about $0.5-1$ minute to complete, wading surveys of even small streams are seldom attempted for channel domains longer than a few hundred meters. Despite these disadvantages, elevation data from wading surveys are needed for submerged channel and waterbody banks that are too shallow for lidar or acoustic surveys.

Review of investigations using other survey techniques provides a basis for establishing a general range of depths where wading surveys are important for collecting bathymetry. To assess the minimal depth for green waveform lidar, Allouis and others (2007) tested and evaluated lidar-derived river bottoms for river reaches with specified roughness and longitudinal slope for the water surface and determined that, for average roughness and no slope, a theoretical lower limit of 0.41 meter $(\mathrm{m})$ was estimated with a 95-percent confidence interval. Feurer and others (2008) determined that airborne lidar bathymetry (ALB) is not generally suitable for mapping depths less than $0.5 \mathrm{~m}$, which is not much different. For depth sounding equipment, Allouis and others (2007) reported a minimal detectable depth of $1.5 \mathrm{~m}$ for multibeam acoustic surveys.

\section{Sound Navigation and Ranging Surveys}

Sound navigation and ranging (acoustic) surveys operate depth sounding equipment that provides a continuous record and chart of the bottom water-body profile (U.S. Bureau of Reclamation, Denver Office, Technical Service Center, 2006). Several types of sonar are used for acoustic surveys: the acoustic Doppler current profiler (ADCP), side-scan sonar, single-beam echo sounders, and multibeam echo sounders. Each system operates on the same principle that involves sending out a sonic pulse and recording the reflected waveform return time to estimate depth based on sound wave velocities. In addition to providing bathymetry, acoustic backscatter returns produced from variations in the density or sound speed of a medium are used to estimate water-body bottom types and biology (Warren, 2010). Compared to lidar surveys, an advantage of using an acoustical survey system is that these systems are usually available at a comparably low cost, and although turbidity can limit the range (side-scan sonar) or create velocity errors (multibeam), sonar can be used with some success in low visibility conditions (National Park Service, 2009). A disadvantage is that acoustic surveys can be time consuming.

Accuracy standards for acoustic surveys are commonly written for nautical charting used for safety of surface navigation and the protection of marine environments (Bergen and Sanders, 2013; Federal Geographic Data Committee, 2000). Because it is difficult to independently verify the accuracy of a hydrographic measurement, the accuracy of a hydrographic 
survey is often based on statistical analysis of repeated equipment calibrations (U.S. Army Corps of Engineers, 2013) described in the International Hydrographic Organization (IHO) (2004) guidelines (Bergen and Sanders, 2013). The IHO accuracy standards are in terms of uncertainty, where vertical uncertainty at the 95 -percent confidence interval is plus or minus ( \pm ) $0.5 \mathrm{~m}$ for areas shallower than $100 \mathrm{~m}$ and $\pm 1.0 \mathrm{~m}$ for areas deeper than $100 \mathrm{~m}$. Horizontal accuracy standards for mechanical or acoustic survey systems vary between \pm 0.25 foot $(\mathrm{ft})$ and $\pm 2.00 \mathrm{ft}(0.0762 \mathrm{~m}$ and $0.6096 \mathrm{~m})$.

The ADCP makes use of the Doppler effect by emitting a sequence of high-frequency pulses of sound that scatter off of moving particles, where a frequency shift is proportional to the speed of the water. A single pass across the river can provide a cross section of the channel bottom. Although the system is not considered optimal for collecting bathymetry, multiple individual beam depths have been used to map stream bathymetry. The velocity data also have been used in design and validation of hydraulic models and for describing performance of existing hydraulic structures (Vermeyen and Wahl, 1999).

Side-scan sonar systems primarily are used to image bottom-surface features. Under optimal conditions, imaging provides photo-realistic pictures and elevations of surrounding topography, not absolute object elevations (Kenny and others, 2003). The NOAA uses side-scan sonar hydrographic surveys to detect objects on the seafloor; most of these systems cannot provide depth information, so they are used in conjunction with single-beam or multibeam sonar systems to meet full bottom coverage specifications (National Oceanic and Atmospheric Administration, Office of Coast Survey, 2015).

A single-beam echo sounder survey uses a single transducer to emit sound and record echoes, or returns, from a river bottom or a lake bottom and can provide continuous output of 20 or more depths per second (U.S. Bureau of Reclamation, Denver Office, Technical Service Center, 2006). These surveys are used for mapping landscape-level attributes including geologic formations, substrates, and circulation patterns (National Park Service, 2009). Survey runs provide a narrow path of depth information, so mapping using this technology can require many close passes through an area to avoid gaps in quantitative depth information or a greater degree of interpolation for mapping lake-bed or channel bottoms (U.S. Bureau of Reclamation, Denver Office, Technical Service Center, 2006); however, when a swath survey or a survey with bottom classification is completed, single-beam echo sounder surveys provide high-resolution bathymetry for very shallow water of less than a 3-m depth (National Park Service, 2009). Compared to other sonar systems such as lidar, aerial imagery, and shallowwater surveys, single-beam sonar is low cost (National Park Service, 2009).

Multibeam acoustic survey systems, considered as a major development in depth sounders, create detailed 3D models of river and lake bottoms (U.S. Bureau of Reclamation, Denver Office, Technical Service Center, 2006; National Oceanic and Atmospheric Administration, 2012). A multibeam acoustic survey system uses multiple transducers and receivers to emit and receive sound to cover a wide swath of a channel bottom perpendicular to the navigation line, where a lateral distance equal to about two times the water depth can be mapped. Compared to single-beam acoustic survey instruments that can provide 20 or more depth soundings per minute, the multibeam acoustic data collection system vessel can operate in rough water and offers greater coverage, and has the capability of continuously collecting several hundreds of thousands of points per minute to produce accurate depictions of subaqueous surfaces and higher-resolution imagery (U.S. Bureau of Reclamation, Denver Office, Technical Service Center, 2006; National Park Service, 2009). The system collects several soundings at once and georeferences them with a RTK-GPS unit to create an accurate depiction of subaqueous surfaces, reducing the interpolation between data points. The result is a more detailed model that displays bottom contours, debris, scour areas, and other bottom conditions.

Disadvantages of multibeam systems are mostly related to shallow-water conditions that can be costly to survey because of limitations on swath width, which translates to requirements for more track lines and time. Also, boat-based operations are difficult in 0 - to $10-\mathrm{m}$ depths because of submerged rocks and irregular coastlines. Some multibeam systems can be tilted for mapping reservoir banks and features such as dam faces and outlet works, but accuracy may be sacrificed because multibeam system error increases in the outer beams (U.S. Bureau of Reclamation, Denver Office, Technical Service Center, 2006). Concerning terrain classification, multibeam backscatter images lack the resolution provided by sidescan sonar imagery, and rigorous ground-truthing is needed to verify the accuracy of substrate classification (National Park Service, 2009). Also, multibeam transducers are rigid mounts to the survey vessel hull, which results in broad angles between the beam and the surface (the grazing angle) that are not conducive to real-time object detection (Brissette and Clarke, 2001).

\section{Light Detection and Ranging Surveys}

Airborne lidar bathymetry surveys collect 3D pointcloud data processed to provide water-body depths based on travel times for blue/green (green) waveforms transmitted from a laser source. The primary use of these green waveform systems has been for coastal surveying, but for reasons described above, inland bathymetric surveys completed using green light can provide a cost-effective, reliable option for surveys sponsored by the private and public sectors. Active research to understand and resolve limitations, evolving guidelines for best survey practices and survey-system techniques, and efforts to improve processing algorithms indicates a broad, pro-active interest in use of lidar surveys for inland bathymetry.

Interpretation of lidar-derived bottom depths is primarily a function of waveform velocities and elapsed time for waveform returns reflected from a target area. Other physical 
parameters such as waveform refraction and dispersion, target location determined by aircraft GPS, and aircraft orientation (pitch, roll, and yaw) are also input for the solution to produce accurate point-cloud bathymetric data (Kinzel and others, 2007). Some well-known commercial ALB systems in use are the Scanning Hydrographic Operational Airborne Lidar System (SHOALS) and the Coastal Zone Mapping and Imaging Lidar (CZMIL) system commonly used by the USACE for coastal zone mapping, the Chiroptera and the Hawk Eye (a SHOALS derivative), and the Laser Airborne Depth Sounder (LADS). The Experimental Advanced Airborne Research Lidar (EAARL) system named EAARL-B is used by the USGS Coastal Marine and Geology Program in cooperative surveys with other USGS offices and programs.

Compared to other optical aerial and satellite imagery remote-sensing techniques, the advantages of laser scanning in river or lake settings, and for topographic mapping, are the ability to measure surface elevations under a canopy cover, the nondependence on lighting conditions, and the ability for the waveform data to provide 3D surfaces (Hohenthal and others, 2011). Also, compared to single-beam sonar or ADCP survey instruments used in conjunction with RTK-GPS, ALB surveys require less survey time. A limitation for inland waterbody ALB surveys has been that low waveform frequencies required for eye-safe operation result in less water-column penetration, a smaller laser spot size (a few meters) and point density, and less resolution than surveys for coastal corridor surveys (Wright and Brock, 2014; Hilldale and Raff, 2008; Allouis and others, 2007); however, with improved techniques developed to collect data with a greater point density and resolution, these issues may be alleviated. Site conditions that cause problems are associated with turbidity and suspended materials in the water column because of air bubbles, fish, or kelp that effect survey data collection (Government of Canada, Fisheries and Oceans Canada, 2014; Hohenthal and others, 2011; Feurer and others, 2008; Kinzel and others, 2007).

These conditions can limit the utility and quality of the ALB surveys to varying degrees with the consequence that reported, optimal survey depths may be different. It is also important to note that if different processing techniques are used, results may vary (Carter and others, 2012; Kinzel and others, 2013).
Vertical accuracy, pulse spacing, and pulse density requirements for the USGS National Geospatial Program (NGP) lidar specification quality levels (QLs) QL0 through QL3 (table 1) are specific to land-surface terrains and mapping water-body and stream/river surfaces (Heidemann, 2014), but examples for vertical accuracies published in lidar-derived bathymetry reports by Bailey and others (2010), Hilldale and Raff (2008), and Kinzel and others (2007) indicate lidar bathymetry vertical accuracies meet QL2 or QL3. For the cited surveys, planimetric accuracies are estimated using RTKGPS survey data in root mean square error calculations. The range for horizontal accuracies $(\mathrm{X}, \mathrm{Y})$ reported for these lidar surveys at specified ground sample distance (GSD), or survey pixel size between 15 and 20 centimeters (cm), is between 100 to $250 \mathrm{~cm}$ (Hohenthal and others, 2011). Compared to the classification of surveys with similar GSDs and associated accuracies, these data meet the American Society for Photogrammetry and Remote Sensing 95-percent confidence level requirements for Class 1 digital planimetric data for 1:1,200to 1:8,000-map scales (American Society for Photogrammetry and Remote Sensing, 2014b).

Minimum green-laser penetration depths that provide good laser waveform returns range from $0.2 \mathrm{~m}$ reported for the EAARL (McKean and others, 2009) and $0.5 \mathrm{~m}$ for the USACE SHOALS system (Feurer and others, 2008). Reported maximum depths range from $10 \mathrm{~m}$ (Kinzel and others, 2007) to between $50 \mathrm{~m}$ and $60 \mathrm{~m}$ (Government of Canada, Fisheries and Oceans Canada, 2014; Hohenthal and others, 2011; Feurer and others, 2008). The Secchi depth, the depth at which a Secchi disk measuring $30 \mathrm{~cm}$ can no longer be seen by the naked eye, is a common, low-cost means for determining the appropriate depth for an optimal lidar survey; however, the variability in the depth measurement capability means calculated depths may be inaccurate. Bresina (2011) determined Secchi depth variability due to solar altitude variation, waves and ripple, and reflection; for the season of testing (May through September), solar altitude affected depth measurements by \pm 7 percent. When the effects of wind and surface reflection were included, the average measurement variability increased to \pm 12 percent and could vary as much as \pm 20 percent.

Table 1. Light detection and ranging specifications for The National Map (Heidemann, 2014).

$\left[\mathrm{RMSE}_{\mathrm{z}}\right.$, root mean square error in the $\mathrm{z}$ (elevation) dimension; NVA, nonvegetated vertical accuracy; $\leq$, less than or equal to; $\geq$, greater than or equal to]

\begin{tabular}{|c|c|c|c|c|}
\hline $\begin{array}{l}\text { Quality level } \\
\text { (OL) }\end{array}$ & $\begin{array}{c}\text { RMSE }_{z} \\
\text { nonvegetated } \\
\text { (centimeter) }\end{array}$ & $\begin{array}{l}\text { NVA at 95-percent } \\
\text { confidence level } \\
\text { (centimeter) }\end{array}$ & $\begin{array}{l}\text { Aggregate nominal } \\
\text { pulse spacing } \\
\text { (average pulse spacing) }\end{array}$ & $\begin{array}{l}\text { Aggregate nominal } \\
\text { pulse density } \\
\text { (pulses per } \\
\text { square meter) }\end{array}$ \\
\hline QL1 & $\leq 10.0$ & $\leq 19.6$ & $\leq 0.35$ & $\geq 8.0$ \\
\hline QL2 & $\leq 10.0$ & $\leq 19.6$ & $\leq 0.71$ & $\geq 2.0$ \\
\hline
\end{tabular}


Nephelometric Turbidity Units (NTUs) measure suspended particles in water and provide an alternative to using the Secchi disk to evaluate appropriate conditions for greenlight lidar. Relative to clarity, at 5 NTUs water is considered visibly cloudy, and at 25 NTUs water is murky (Manitoba Water Stewardship and Manitoba Health, 2011). Water-quality data collected for an EAARL survey of the lower Boise River, Idaho, indicate laser energy was incomplete when turbidity was between 4.2 and 19.3 NTUs (Skinner, 2009), corroborating the 5 NTUs for visibly cloudy water and suggesting an upper limit of NTU values for optimal lidar-bathymetry data collection.

Reports for inland lidar-bathymetry projects completed by USGS offices include field data for site conditions and processing that provide insight for advantages and disadvantages that should be compiled and expanded upon as a guide for planning and completing lidar bathymetry. In a survey completed by McKean and others (2009), the accuracy of the EAARL system lidar survey data collected at Bear Valley Creek, Idaho, to derive channel geometry for wetted cross sections was within a few percent of data values from field observations (ground surveys). The largest channel-mapping errors happened along stream banks as a consequence of the $20-\mathrm{cm}$ footprint of the laser waveform reflection being coarser than the abrupt stream-bank edge because few measurements were made on the faces of steep banks, and because of smoothing during data gridding. The DEMs derived from the ALB data generally had poorer horizontal accuracy compared to vertical accuracy as a result of the $20-\mathrm{cm}$ laser-reflection spot size, poorer location of laser point measurements, and spacing of point measurements that seldom supported DEMs with grid cells smaller than $1 \mathrm{~m}$ (McKean and others, 2009). Investigators concluded that aquatic-terrestrial, green-waveform lidar is most advantageous for mapping long channel segments and stream networks that are not feasible to map with field surveys but not as useful for mapping point elevations, channel cross sections, or short reaches.
Kinzel and others (2013) completed a field study that assessed environmental conditions and postprocessing algorithms (the maximum peak [MP] and last peak [LP] solutions) for ALB data that can happen because of different processing algorithms. Lidar survey results are then compared to samelocation wading and ADCP data to provide an indication of the accuracy and utility of lidar surveys (table 2). Study locations include two reaches (Sheridan Bar and Chapman Ranch) on the Trinity River in California, a site (Tree of Heaven) on the Klamath River in Oregon, and a site at the confluence of the Blue and Colorado Rivers in Colorado.

The LP processing algorithm was developed (June 2011) to reduce problems associated with the MP algorithm processing, though the MP algorithm was determined to select stronger peaks from turbidity reflection over a much weaker bottom surface reflection or albedo (Kinzel and others, 2013). River survey lengths varied between 0.4 and $1.4 \mathrm{~m}$, mean depths ranged from 0.91 to $1.84 \mathrm{~m}$, and mean widths ranged from 29 to $57 \mathrm{~m}$. Point density ranged from 0.03 to 0.67 point per square meter $\left(\mathrm{pts} / \mathrm{m}^{2}\right)$. Trinity River and Klamath River turbidities were 2 and 3 NTU, respectively. There was no turbidity value reported for the Colorado River, and a turbidity of 6.1 NTU was reported for the Blue River.

Vertical accuracy root mean square errors in the $z$ (elevation) dimension ( $\mathrm{RMSE}_{z}$ ) for the comparison between groundtruth wading surveys or sonar surveys and the EAARL survey for the MP or LP algorithms range from 0.14 to $0.76 \mathrm{~m}$ with the differences between sonar and lidar surveys greater than the differences between wading and lidar surveys (table 2). When these RMSEs are converted to RMSE $\mathrm{Z}_{z}$ accuracies (Heidemann, 2014), only the confluence of the Blue and Colorado Rivers site survey with a QL3 meets the NGP lidar specification for $\mathrm{RMSE}_{z}$ accuracy though this survey does not meet point density requirements. Even with the improved processing algorithm, the survey results indicate that there still are some issues with the LP algorithm to process the lidar returns (table 3). Also, the LP survey was able to locate the

Table 2. Light detection and ranging bathymetry survey parameters.

[The data in this table are from Kinzel and others (2013). ALPS, airborne lidar processing system; pts $/ \mathrm{m}^{2}$, points per square meter; RMSE, root mean square error; MP, major peak; sonar, sound navigation and ranging; --, no value; LP, last peak]

\begin{tabular}{|c|c|c|c|c|c|c|}
\hline $\begin{array}{l}\text { Reach, } \\
\text { river }\end{array}$ & $\begin{array}{c}\text { ALPS } \\
\text { algorithm }\end{array}$ & $\begin{array}{c}\text { Compared } \\
\text { survey method }\end{array}$ & $\begin{array}{l}\text { Point density } \\
\left(\mathrm{pts} / \mathrm{m}^{2}\right)\end{array}$ & RMSE & $\begin{array}{c}\text { RMSE accuracy } \\
\text { (1.96xRMSE) }\end{array}$ & $\begin{array}{l}\text { RMSE accuracy } \\
\text { (1.96xRMSE) }\end{array}$ \\
\hline $\begin{array}{l}\text { Sheridan Bar, } \\
\text { Trinity River }\end{array}$ & MP & Sonar & 0.45 & 0.52 & 1.01 & 2 \\
\hline \multirow{2}{*}{$\begin{array}{l}\text { Chapman Ranch, } \\
\text { Trinity River }\end{array}$} & MP & Sonar & 0.67 & 0.38 & 0.74 & 2 \\
\hline & MP & Wading & -- & 0.25 & 0.49 & \\
\hline \multirow{2}{*}{$\begin{array}{l}\text { Confluence, } \\
\text { Blue and Colorado } \\
\text { Rivers }\end{array}$} & LP & Sonar & 0.34 & 0.15 & 0.29 & 6.1 \\
\hline & LP & Wading & -- & 0.14 & 0.27 & -- \\
\hline
\end{tabular}


Table 3. Light detection and ranging results from different river bed mediums.

[The data in this table are from Kinzel and others (2013). <, less than]

\begin{tabular}{lccc}
\hline \multicolumn{1}{c}{ River } & \multicolumn{1}{c}{ Bottom surface } & Major peak & Last peak \\
\hline Trinity River & Gravel bedded & $\begin{array}{c}\text { Higher cross-section elevations; } \\
\text { imprecise horizontal positioning }\end{array}$ & $\begin{array}{c}\text { Omission of survey points; overpre- } \\
\text { diction of depth, especially along } \\
\text { channel margins. Noise incorrectly } \\
\text { identified along channel margins. }\end{array}$ \\
\hline $\begin{array}{c}\text { Klamath River } \\
\text { Confluence of the Blue } \\
\text { and Colorado Rivers }\end{array}$ & $\begin{array}{c}\text { Thalweg along bedrock, gravel, } \\
\text { cobbles, and (or) sand bed }\end{array}$ & $\begin{array}{c}\text { No bottom surface detected unless } \\
\text { it is }<0.5 \text { (channel margin) }\end{array}$ & $\begin{array}{c}\text { Derived elevations are above bottom } \\
\text { heights. }\end{array}$ \\
& & $\begin{array}{c}\text { Derived elevations are above bot- } \\
\text { tom heights; bottom reflectance } \\
\text { incorrectly identified within the }\end{array}$ & $\begin{array}{c}\text { Locate channel bottom as a weaker } \\
\text { inflection point. }\end{array}$ \\
\hline
\end{tabular}

Colorado River channel bottom in areas that the MP processes missed but omitted some survey points at the Trinity River. Both solutions have relatively high RMSEs when compared to sonar data.

Surveys at Chapman Ranch and Sheridan Bar, both with turbidities of 2 NTU, produced RMSEs of 0.74 and 0.49 (for sonar and wading, respectively) at Chapman Ranch and 1.01 and $0.66 \mathrm{~m}$ (for sonar and wading, respectively) at Sheridan Bar. A comparison of LP data indicates that the RMSE accuracy for the Tree of Heaven site, Klamath River, with a turbidity of $3 \mathrm{NTU}$, is $1.49 \mathrm{~m}$, but at the confluence of the Blue and Colorado Rivers where the turbidity was 6.1 NTU, the RMSEs ( 0.29 and $0.27 \mathrm{~m}$ for sonar and wading, respectively), are less (Kinzel and others, 2013). The inconsistent relation of the RMSEs to turbidity values suggests that turbidity alone should not be used to determine appropriate conditions for lidarbathymetry surveys.

Regarding survey techniques, the highest point-density value for the Chapman Ranch, $0.67 \mathrm{pt} / \mathrm{m}^{2}$, is associated with higher RMSE accuracy values than those measured at the confluence of the Blue and Colorado Rivers where the point density was $0.34 \mathrm{pts} / \mathrm{m}^{2}$. The lowest point density, $0.03 \mathrm{pts} / \mathrm{m}^{2}$, is for the Tree of Heaven site, Klamath River, which had the largest RMSE accuracy value, $1.49 \mathrm{~m}$, as expected.

Results for the Kinzel and others (2013) study indicate that the most consistent correlation with estimated accuracies is related to the streambed medium (table 3). When the type of mediums and associated RMSEs for the different sites are compared, the highest RMSEs are for the mixed bedrock, gravel, cobble, and sand medium, the middle-range RMSEs are for gravel-bedded rivers, and the lowest RMSEs are for the sandy river bottom. The USGS Coastal Marine and Geology Program presented a comparison of EAARL-B survey results with ground-truth differences (standard deviations) by river bed (substrate) type developed for the Delaware River inland bathymetry project completed in collaboration with the USGS Coastal National Elevation Dataset (CoNED) Program (Wright and Brock, 2014) that generally correlates with the relation of accuracy and substrate deduced from the survey results of Kinzel and others (2013). The analyses from Wright and Brock (2014) and Kinzel and others (2013) also agree with the overview of lidar data collected in fluvial environments presented in Hohenthal and others (2011), who report that lidar survey accuracies are best across smooth bedrock surfaces. Less accurate survey results collected from heterogeneous cobble and boulder beds are explained as the result of adjacent clasts preventing the penetration of laser beams between clasts, which leads to an overestimation of surface elevation. Hohenthal and others (2011) also describe lidar survey issues related to steep riverbanks reported in a study that determined elevation for lidar-Digital Terrain Models substantially increased on slopes greater than 15 percent under tree cover.

Lidar-derived inland bathymetry is new and a more complete assessment of suitable conditions is needed to propose the best use of resources to provide quality elevation data. Lidar survey reports from fieldwork described in McKean and others (2009) and Kinzel and others (2007) provide good examples of parameters for collecting lidar survey data; moreover, the results from these surveys point to the need for more well-defined site conditions that optimize or limit successful lidar survey results. Establishing successful survey criteria and providing information for understanding limiting site conditions can help develop cost-effective flight plans. Pilot surveys for sites selected to test processing algorithms and evaluate results for variable site conditions, including different bed mediums, bank slopes, flood and drought attributes, shape (straight versus meandering), depths, and other features, will provide the background data needed to develop standards and techniques.

\section{Breaklines}

Breaklines are vector features used to enhance 3D elevation data products to delineate hydrographic features (ponds, lakes, wide rivers or streams, and stream centerlines), hydrologic structures, transportation features, and cartographic 
features such as surface slopes, roads, or map contours. Breaklines also can depict the cross-sectional details of a stream, to include the top and bottom of the stream banks or flood plain edge (Meade, 2008). Because lidar returns reflected off of objects may have ambiguities in locations, breaklines have been incorporated into some surface models such as the triangulated irregular network (TIN) to constrain the surface models with the goal to improve lidar data modeling. Soft breaklines conform to original surface geometry and hard breaklines are used to create new, three-dimensional nodes in a modeled surface.

The DEMs requiring hydroenforcement techniques to depict water features use breaklines as water feature center lines to ensure continuous downward sloping of water flow, which accounts for rivers and reservoirs with a gradient change in elevation along their length consistent with their natural behavior and the surrounding topography. The NGP lidarbase specification requirements for breaklines used to develop DEMs (appendix 1) define the minimum features for which breaklines will be created and delivered with the hydroflattened DEM surface, the classified point cloud, and the raw swath data (Heidemann, 2014), and accuracy standards that align with the American Society for Photogrammetry and Remote Sensing (2014a).

As recently as 2013, opinions have differed on the suitability of lidar data for breakline generation using lidar intensity data. One reason lidar data might not be considered suitable for developing breaklines has been that other remotesensing imagery must be used to augment the hydrographicsurvey data because laser returns can be scattered and are reflected over water causing unsightly and unnatural artifacts in the derived TIN and DEM (Dharmapuri, 2013). Another reason for questioning the suitability has been that when lidar nominal-pulse spacing is between 5 and $10 \mathrm{~m}$, it is difficult to determine the location of breaklines at the tops and bottoms of stream banks that fall somewhere between the elevation points; however, 1-m pulse-spacing surveys are becoming more common and lidar-base specifications for 3DEP data procurement include requirements for nominal pulse spacing, the minimum number of lidar waveform pulses per grid cell, with upper and lower limits ranging from less than or equal to $0.35 \mathrm{~m}$ to $1.14 \mathrm{~m}$ (table 1) (Heidemann, 2014). Interestingly, for creating DEMs with a resolution of $1 \mathrm{~m}$, the Federal Emergency Management Agency had required breaklines, but now specifies breaklines are optional because the denser nominal pulse spacing alleviates the need for them (Maune, 2011).

\section{Importance of Geomorphic and Hydraulic Site Conditions}

Geomorphic and hydraulic site conditions for river systems and water bodies are critical to understanding channel bed configurations, water-clarity properties, and water feature bed depths, all of which can limit to varying degrees the utility of lidar surveys for bathymetric data collection. To help ensure the best use of 3DEP resources, a lidar-based bathymetry program should implement requirements for developing systematic documentation of geomorphology as a component of an inland bathymetry data baseline. Similar to the survey data parameters collected in investigations previously described (McKean and others, 2009; Kinzel and others, 2007), this baseline can be a valuable resource for developing an understanding of options and issues for completing successful inland bathymetry surveys under variable site conditions.

A proposed database of documentation for geomorphologic features to attribute bathymetric survey sites includes identification of the waterbody medium, underlying site geology, bank composition and slope data, sinuosity attribution (for stream/rivers), evidence of channel migration or erosional features, sediment load, and turbidity. Additionally, Secchi depths and other hydraulic parameters including discharge records that can be used to identify changes in bedload or changes in water volumes, correlation of seasons to trends in discharge, connectivity to other channels or flood plains that may influence changes in channel geometry, and manmade structures that modify the natural flow of surface or groundwater should be considered for inclusion in a bathymetry survey data baseline. In addition, documentation of operational parameters including system setup, height of the lidar signal above the area of interest, processing techniques, and processed data accuracy provide important information for assessing and understanding the results of a lidar bathymetry survey.

In some cases, channel stability controlled by seasonal changes in rainfall and flood or drought events, available suspended sediment load, and scour and fill processes that affect site conditions (Leopold and Maddock, 1953) may be important factors for identifying candidate river surveys, the need for short- and long-term river or lake monitoring programs, or for carrying out periodic bathymetric survey updates. Visual indicators of lateral channel stability may include channel migration and the nature of bank erosion, which are influenced by land cover, hydrologic regime (Krasovskaia, 1995), bank composition, underlying geology, and other factors (Giardino and Lee, 2011). In general, laterally stable streams are characterized by healthy, upright, woody vegetation, low banks that are not susceptible to mass wasting (gravity failures), and a flood plain that is connected to the river and active in moderate-flow events. Laterally unstable streams may be characterized by over-heightened or steepened banks that are susceptible to mass wasting, which is evidence of geotechnical failure planes along river banks; lack of diverse, upright woody vegetation; and a flood plain that is disconnected from the channel so that moderate to high flows remain within the channel banks (Federal Highway Administration, 2006).

Human-induced changes that can affect water feature stability include construction for dams, reservoirs, and aqueducts; modifications to riparian habitat; and changes in landscape because of agricultural enterprises, all of which create artificial conditions and changes (Shields and others, 2000; Graf, 2006; Federal Highway Administration, 2006; Micheli and others, 
2004). The types of changes include landform deposition or erosion and shifting channel bottoms, position, and pattern; for example, in Kansas, a study of changes in river/stream stage associated with mean annual discharge determined that channel-bed lowering happened downstream from a large reservoir, and decreasing channel-bed elevations ranged from less than 1 $\mathrm{ft}$ to more than $9 \mathrm{ft}(0.3048 \mathrm{~m}$ to more than $2.7432 \mathrm{~m}$, respectively) (Juracek, 2001). As another example, Mossa and Coley (2015) evaluated planform changes with and without flood plain sand and gravel mining along the Pascagoula River, Mississippi, and developed change indices to identify the degree and type of instability (erosion, deposition, between, or unchanged) and to quantify the rates of change.

Well-structured channel geomorphology data bases used to characterize stream stability developed by the Federal Highway Administration (FHWA) and the USACE provide good examples for developing a lidar survey geomorphology baseline in the 3DEP. Although for different purposes, the qualitative and quantitative characterization for assessing channel stability aligns with the type of geomorphic baseline proposed herein (Federal Highway Administration, 2006; U.S. Army Corps of Engineers, 1994). The FHWA method addresses geomorphic and hydraulic factors affecting stream stability, and other evaluation criteria including attributes for 14 physiographic units and subunits (adopted from U.S. Geological Survey, 2003); a range of bank materials and complexities; and stream types assigned based on variability in valley slope, sediment supply, and water discharge. The USACE has suggested a three-level stability analysis for the purpose of stream restoration design. Streams are classified based on location and processes within a watershed, and landform types. The analysis identifies glaciated and regulated streams, braided rivers, meandering alluvial rivers, deltas, modified channels, and other categories including engineered streams. Level 1 is a geomorphic assessment that evaluates watershed development and land use, flood plain characteristics, channel planform, stream gradient, and other factors (U.S. Army Corps of Engineers, 1994). Level 2 is a hydraulic-geometry assessment, and level 3 is an analytical-stability assessment that includes a sediment transport study. Stream order that classifies a stream reach based on the relation to all other upstream and downstream reaches and qualitatively ranks comparatively small to main surface-water reaches in a watershed could also be used to streamline or constrain survey targets.

\section{Integration and Interpolation Techniques for Topographic and Bathymetric Digital Elevation Models}

Challenges for integrating bathymetry and topographic lidar data to create a continuous DEM can include a narrow overlap of data, differences in data generated by each system, data noise, lack of control points, gaps in bathymetric lidar data, and perhaps most important, the establishment of a consistent vertical datum (Graham, 2012). Software programs such as the NOAA North America Datum Conversion Utility, which can transform latitude and longitude coordinate values, are used when horizontal datum transformations are required.

To address the important need for vertical datums, the NOAA National Geophysical Data Center implemented the vertical datum transformation tool, VDatum. Developed to integrate coastal topographic and bathymetric elevation data, VDatum is designed to vertically transform geospatial data among a variety of tidal, orthometric, and ellipsoidal vertical datums, which allows users to convert their data from different vertical references into a common system (National Oceanic and Atmospheric Administration, National Geophysical Data Center, 2014a). The program has been used successfully by NOAA and other Federal, state, and private projects. Recently, the Coastal 3DEP CoNED Program used the VDatum tool for the Northern Gulf of Mexico project, integrating topographic, bathymetric, and topobathymetric data from various sources to develop regional topobathymetric mapping in the offshore to surrounding Northern Gulf of Mexico coastal region (Jeffrey Danielson, U.S. Geological Survey, written commun., June 2015).

For some datasets, interpolation methods are essential for integration of bathymetric and topographic data, in order to provide adequate point spacing that is compatible with 3DEP lidar requirements (Heidemann, 2014) and to ensure a smooth representation for the transition from a bathymetric to a topographic surface. Even for the same river and using the same interpolation technique, data results for two different surveys can vary because of a difference in survey point density and locations relative to the linear and cross-section profiles, structures, and vegetation. In addition to creating TINs, standard methods used to develop interpolated bathymetry have included the following: inverse-distance weighting; elliptical inverse-distance weighting; natural neighbor (weighting based on area of surrounding points); thin plate spline with tension; regular spline, ordinary kriging, and anisotropic ordinary kriging; and Topogrid, the Topo to Raster tool available in ArcGIS (Merwade and others, 2006).

\section{Channel Cross-Section Interpolation and Integration}

Cross-sectional inland bathymetry surveys available through USGS investigations (Kinzel, 2013) and other sources such as the USACE can provide an important source for bathymetric data. The USGS collects bathymetric survey data, including channel or water-body cross sections, for research, studies, and operational programs (Kinzel, U.S. Geological Survey, 2014). Provided the data gridding and accuracies are compatible with standards for 3DEP lidar data products (Heidemann, 2014), these surveys can be a valuable source of inland bathymetry coverage; moreover, evaluating these survey data for integration meets the NGP objectives to avoid 
duplication of effort and fostering cooperative projects. Even considering the future direction for enhanced elevation data in the form of high resolution lidar survey products (U.S. Geological Survey, 2014a), advantages for ingesting existing cross-sectional data from other sources should not be overlooked as a strategy for improving elevation and hydrography resources. Also, cross-section surveys may provide geomorphic data and can provide baseline channel geometries as control points for new or extended surveys.

In an assessment of interpolation techniques to integrate cross-sectional data for river channels to create a continuous topographic surface in DEMs, Merwade and others (2006, 2008) present comparisons between standard isotropic (uniform physical properties) spatial interpolation methods in a Cartesian coordinate system and anisotropic (nonuniform physical properties) interpolation techniques in a flow-oriented curvilinear (channel fitted) coordinate system to study the effects of channel anisotropy in determining bathymetry from point measurements (table 4). In the channel-fitted solution, anisotropy is the nonuniform thalweg to river bank differences where a thalweg represents a line joining the lowest points along the entire length of a stream bed or valley in its downward slope, defining its deepest channel. In this floworiented coordinate system, $s$ is the distance along a thalweg, and $n$ represents the perpendicular distance from a point to the river thalweg. Procedures for transforming coordinates from a Cartesian to a channel-centered frame of reference to the flow-oriented coordinate system are described in Merwade and others (2006) and Legleiter and Kyriakidis (2007).

A comparison of RMSEs calculated for different interpolation techniques applied in a Cartesian coordinate system and the channel-fitted flow-oriented coordinate system show that anisotropic spatial interpolation methods applied in the flow-oriented coordinate system are similar for some isotropic solutions, but that the anisotropic kriging method and the elliptical inverse-distance weighting method (only used for the anisotropic condition) are significantly better, with an estimated 40 percent reduction in RMSE (Merwade and others, 2006). The comparisons also show that spline methods are most sensitive to interpolation parameters (number of points and weights); and that Topogrid, natural neighbor, inversedistance weighting, and kriging methods worked better than spline methods.

A fairly straightforward method for combining or integrating topographic and bathymetric datasets presented in Merwade and others (2008) uses an algorithm that creates a smooth transition between these data in a buffered zone for the intersection of river banks and surrounding topography:7

Table 4. Root mean square error Cartesian and channel-fitted coordinate system statistics for interpolation techniques.

[Modified from Merwade and others (2006). Neither TopoGrid nor natural neighbor methods incorporate user-defined parameters. RMSE, root mean square error; $N$, number of points; $p$, power; $\sigma$, weight factor for the tension spline; $t$, weight factor for the regularized spline; --, no value; $\alpha_{r}$, anisotropy factor]

\begin{tabular}{|c|c|c|c|c|c|}
\hline \multirow[b]{2}{*}{ Method } & \multirow[b]{2}{*}{$\begin{array}{l}\text { Parameter values } \\
\text { for minimum RMSE }\end{array}$} & \multicolumn{4}{|c|}{ RMSE statistics } \\
\hline & & Minimum & Maximum & Average & $\begin{array}{l}\text { Standard } \\
\text { deviation }\end{array}$ \\
\hline \multicolumn{6}{|c|}{ Root mean square error statistics for different methods in Cartesian $(x, y)$ coordinate system } \\
\hline Inverse distance weighting & $N=8, p=2$ & 0.5234 & 0.5540 & 0.5348 & 0.0092 \\
\hline Tension spline & $N=8, \sigma=500$ & 0.4435 & 0.9822 & 0.5177 & 0.1291 \\
\hline Regularized spline & $N=8, t=50$ & 0.4566 & 1.7989 & 0.7487 & 0.3955 \\
\hline Ordinary kriging & $N=50$ & 0.4087 & 0.4376 & 0.4190 & 0.0115 \\
\hline Anisotropic kriging & $N=50$ & 0.4610 & 0.5054 & 0.4787 & 0.0168 \\
\hline Topogrid & -- & 0.3940 & -- & -- & -- \\
\hline Natural neighbor & -- & 0.4218 & -- & -- & -- \\
\hline \multicolumn{6}{|c|}{ Root mean square error statistics for different methods in channel-fitted $(s, n)$ coordinate system } \\
\hline Inverse distance weighting & $N=8, p=2$ & 0.5234 & 0.5540 & 0.5348 & 0.0092 \\
\hline Tension spline & $N=8, \sigma=500$ & 0.4435 & 0.9822 & 0.5177 & 0.1291 \\
\hline Regularized spline & $N=8, t=50$ & 0.4566 & 1.7989 & 0.7487 & 0.3955 \\
\hline Ordinary kriging & $N=50$ & 0.4087 & 0.4376 & 0.4190 & 0.0115 \\
\hline Anisotropic kriging & $N=50$ & 0.4610 & 0.5054 & 0.4787 & 0.0168 \\
\hline Topogrid & -- & 0.3940 & -- & -- & -- \\
\hline Natural neighbor & -- & 0.4218 & -- & -- & -- \\
\hline $\begin{array}{l}\text { Elliptical inverse dis- } \\
\text { tance weighting }\end{array}$ & $N=10, p=2, \alpha_{r}=5$ & 0.2779 & 0.4047 & 0.2999 & 0.0302 \\
\hline
\end{tabular}




$$
\frac{Z_{s} * x+Z_{c} *\left(B_{D}-x\right)}{B_{D}}
$$

where

$$
\begin{gathered}
\text { Zc is the elevation of the buffer boundary at the } \\
\text { channel bank, } \\
Z s \quad \text { is the elevation of the buffer boundary in the } \\
\text { surrounding topography, } \\
x \quad \text { is the distance of point P from the channel } \\
\text { bank, and } \\
B_{D} \quad \text { is the buffer distance from the channel bank } \\
\text { and surrounding topography. }
\end{gathered}
$$

An advantage to this solution is that it allows a user to specify an area of an abrupt transition and choose to not apply the smoothing technique or to modify the algorithm to incorporate a weighting scheme. For out-of-channel cross sections, the same procedure is applied by creating a buffer between cross sections and surrounding topography.

\section{Distribution and Coverage of Existing Inland Bathymetry Surveys}

Compiled surveys are presented for the U.S. mainland and separately for the coastal corridor that is commonly surveyed by the NOAA and USACE. These coastal surveys are included as a possible source for acquired bathymetry integration because data from these can supply channel bathymetry where river reaches forming deltaic and estuarine environments drain into estuaries and lagoons in intertidal zones. The NOAA and USACE also collect bathymetry for some regions of the Great Lakes. Understanding these bathymetry data sources can help avoid duplicate efforts and contribute insight into survey metrics important for planning and completing successful bathymetric surveys.

\section{Mainland Surveys}

Coverages for river surveys range in length from less than a mile to hundreds of miles. Lake survey coverages range from about 11 acres (0.02 square mile [ $\left.\mathrm{mi}^{2}\right]$; 0.044 square kilometer $\left.\left[\mathrm{km}^{2}\right]\right)$ to more than 67,000 acres (109 $\mathrm{mi}^{2} ; 271.14 \mathrm{~km}^{2}$ ) (tables 5, 6, and 7). Survey information is listed in appendix 2.

Some listed projects include more than one location (appendix 2); for example, for the Upper Mississippi River System project, the Upper Midwest Environmental Sciences Center has collected about 888 miles (mi) (1,429 km) of bathymetry at selected sites along the Mississippi River coursing through Minnesota, Wisconsin, Iowa, Illinois, and Missouri (fig. 1). The USACE also collects channel maintenance surveys (see below) that provide geometry for river

\begin{tabular}{|c|c|c|c|}
\hline Survey & $\begin{array}{l}\text { Survey area, } \\
\text { square mile }\end{array}$ & $\begin{array}{c}\text { Survey length, } \\
\text { mile }\end{array}$ & Data format \\
\hline \multicolumn{4}{|c|}{ Lakes } \\
\hline MW-12 & 5 & -- & pdf \\
\hline MW-16 & 2 & -- & pdf \\
\hline MW-28 & 0.1 & -- & TIN \\
\hline MW-30 & 0.38 & -- & TIN \\
\hline $\mathrm{NE}-5$ & -- & -- & TIN; pdf \\
\hline NE-6 & 5 & -- & Text \\
\hline NE-8 & 0.21 & -- & TIN \\
\hline NW-5 & 3.354 & -- & DEM; .eOO \\
\hline NW-11 & 109 & -- & TIFF; shapefile \\
\hline SW-7 & 0.03 & -- & TIN \\
\hline SW-9 & 2 & -- & TIN \\
\hline SW-10 & 0.38 & -- & TIN; shapefile \\
\hline \multicolumn{4}{|c|}{ Rivers } \\
\hline $\mathrm{AK}-1$ & 0.004 & -- & pdf; cross sections \\
\hline $\mathrm{AK}-3$ & -- & 0.32 & Text; cross sections \\
\hline MW-6 & -- & 33 & Text \\
\hline MW-24 & -- & 4 & TIN; text; shapefile \\
\hline MW-25 & -- & 550 & TIN \\
\hline MW-29 & -- & 2.49 & DEM; cross sections \\
\hline NE-1 & -- & 29.47 & Text; cross sections \\
\hline $\mathrm{NE}-4$ & 11 & -- & Raster \\
\hline NW-6 & -- & 3 & Text \\
\hline NW-9 & -- & 127 & Raster \\
\hline NW-4 & -- & 28 & DEM \\
\hline NW-12 & -- & 0.2 & Text \\
\hline NW-13 & -- & 12 & Text; pdf; shapefile \\
\hline SW-4 & -- & 28 & TIN \\
\hline SW-11 & -- & 35 & GIS \\
\hline
\end{tabular}
channels in this region. In a survey for a section of the lower Susquehanna River, bathymetric data were collected for three
Table 5. Acoustic inland bathymetric surveys for lakes and rivers.

[MW, Midwest; --, no value; pdf, portable document format; TIN, triangulated irregular format; NE, Northeast; NW, Northwest; DEM, digital elevation model; TIFF, tagged image file format; SW, southwest; AK, Alaska; GIS, geographic information system] 
Table 6. Light detection and ranging for inland bathymetric river surveys.

[MW, Midwest; --, no value; LAS, industry-standard binary format for storing airborne lidar data; NW, Northwest; DEM, digital elevation model]

\begin{tabular}{lccc}
\hline Survey & $\begin{array}{c}\text { Survey area, } \\
\text { square mile }\end{array}$ & $\begin{array}{c}\text { Survey length, } \\
\text { mile }\end{array}$ & Data format \\
\hline MW-8 & 4 & -- & LAS \\
NW-1 & -- & 0.002 & LAS; DEM; text \\
NW-4 & 11 & -- & DEM \\
\hline
\end{tabular}

Table 7. Combined techniques for inland bathymetry lake and river surveys.

[MW, midwest; pdf, portable document format; --, no value; lidar, light and detection ranging; LAZ, a compressed las file; P, Pacific; DEM, digital elevation model]

\begin{tabular}{lclc}
\hline Survey & $\begin{array}{c}\text { Survey area, } \\
\text { square mile }\end{array}$ & \multicolumn{1}{c}{ Technique } & Data format \\
\hline MW-3 & 0.22 & Acoustic; wading & .e00; pdf \\
MW-31 & -- & Acoustic; lidar & LAZ; text; GeoTiff \\
P-2 & 191 & Acoustic; lidar & DEM; .eOO \\
P-3 & 1,364 & Acoustic; lidar & DEM \\
\hline
\end{tabular}

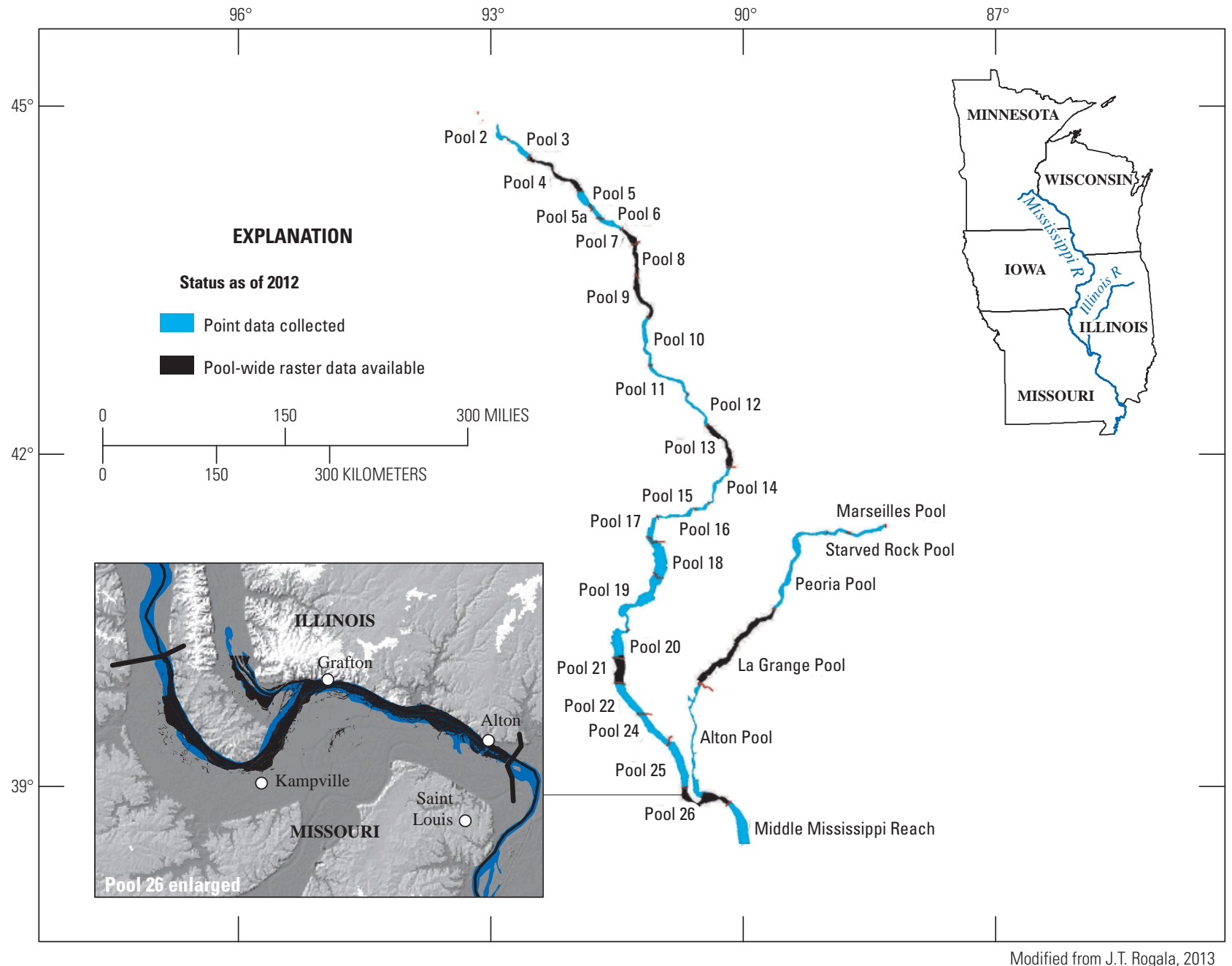

Figure 1. Upper Mississippi River System completed pool bathymetric surveys. 
reservoirs along the length of the main river channel. The Clark and Conowingo Lake surveys measured about $9 \mathrm{mi}$ $(14.48 \mathrm{~km})$ each, and the Aldred Lake survey measured about $11.5 \mathrm{mi}(18.5 \mathrm{~km})$ for a total of more than $20.5 \mathrm{mi}(33 \mathrm{~km})$ of bathymetric surveying (Langland, 2009). Lake bathymetric surveys covering multiple sites are reported in the following:

- Richards (2013);

- Linhart and Lund (2008);

- NOAA reports for Great Lakes surveys (National Oceanic and Atmospheric Administration, National Geophysical Data Center, 2014b);

- the Montana Yellowstone River Corridor (Montana State Library, 2005);

- the Columbia River (Brunner, 2013); and

- Ohio River Community Hydrologic Engineering Center (HEC) River Analysis System (RAS) (HEC-RAS) Model (Adams and others, 2010).

The total surface area and total length of bathymetry surveys reviewed are about 136,345 acres (213 mi²; $\left.552 \mathrm{~km}^{2}\right)$ and more than 5,100 mi (8,207 km), respectively (table 8). Based on surveys compiled, acoustic surveys account for about 60 percent of collected bathymetry surveys, lidar techniques account for about 18 percent of the surveys, and a combination of techniques account for about 20 percent of the compiled inland bathymetry surveys. Wading survey data have

Table 8. Acoustic, light detection and ranging, and combined inland bathymetry survey coverages for lakes and rivers

[MW, midwest; lidar, light detection and ranging; TIN, triangulated irregular network; GIF, graphics interchange format; NW, Northwest; DSM, digital surface model; DEM, digital elevation model; gdb, geodatabase; P, Pacific; sonar, sound navigation and ranging; pdf, portable document format; SE, Southeast]

\begin{tabular}{|c|c|c|c|}
\hline Survey & $\begin{array}{c}\text { Survey } \\
\text { length, } \\
\text { mile }\end{array}$ & Technique & Data forma \\
\hline MW-10 & 888 & $\begin{array}{l}\text { Acoustic; lidar; photoimagery; } \\
\text { breaklines }\end{array}$ & TIN; GIF \\
\hline NW-2 & 477 & $\begin{array}{l}\text { lidar; DSM; breaklines (orthopho- } \\
\text { tography, planimetric features) }\end{array}$ & $\begin{array}{l}\text { TIN; DEM; } \\
\text { text }\end{array}$ \\
\hline NW-3 & 130 & $\begin{array}{l}\text { lidar; orthophotography; planform } \\
\text { feature gdb; aerial photography }\end{array}$ & TIN; DEM \\
\hline $\begin{array}{l}\text { NW-7 } \\
\text { (and } \\
\text { P-4) }\end{array}$ & 137 & lidar; wading; sonar & DEM; text \\
\hline NW-8 & 146 & $\begin{array}{l}\text { lidar; hydraulic modeling cross } \\
\text { sections }\end{array}$ & $\begin{array}{c}\text { Text; } \\
\text { shapefile; } \\
\text { pdf }\end{array}$ \\
\hline NW-10 & 60 & Acoustic; lidar & Raster \\
\hline SE-2 & 124 & Sonic; wading & Text \\
\hline
\end{tabular}

been and are still important for developing cross sections and along-river profiles in shallow or muddy rivers and rivers with vegetated or steep banks that may be unsuitable for acoustic or lidar data collection. Further collaboration with water and other physical science programs could provide data for rivers that are not otherwise available but which may provide control points for validation of remote sensing and acoustic bathymetry surveys and for developing smooth elevation contours.

Most of inland bathymetry survey project data is produced as a TIN or DEM product. Other formats include text (ASCII, Excel, or ArcGIS), portable document format (pdf), and ArcGIS .eOO or shapefiles that can be converted to a digital image format. As for TINs or DEMs, there is some loss of accuracy that would need to be evaluated with respect to lidar survey data requirements that conform to accuracy standards for the American Society for Photogrammetry and Remote Sensing (ASPRS; 2014b).The ASPRS standards specific to lidar data quality levels are based on several parameters including estimated accuracies, required number of discrete waveform returns, lidar intensity values, nominal pulse spacing and density of lidar point measurements, data voids, spatial distribution and regularity, and other requirements (Heidemann, 2014). Although most of these requirements are specific to lidar systems, candidate survey metadata, estimated cumulative errors (the result of all errors affecting data values) used to calculate horizontal and vertical accuracies for the survey data, data collection grids for the original data and for developed data, survey control points, and possibly other factors can be assessed to determine if the surveys are eligible for integration in the 3DEP. The age of candidate survey data also may be important, so that land surface stability, stream channel migration, public and private use, and major weather events of the surveyed region may be part of a candidate survey assessment. Evaluation of historic and more recent National Agricultural Imagery Program imagery available for downloads and in GoogleEarth provides capabilities for easily accessible visual inspections.

\section{Coastal Corridor Bathymetry}

The USACE, NOAA, and more recently the USGS provide coastal zone bathymetric surveys that cover estuarine and lagoonal embayments or in some places extend inland along river channels. These surveys provide bathymetry data that can be important to developing the 3DEP where no other survey data are available and for developing seamless topobathymetry elevation contours. Coastal survey data also can serve as control points for inland surveys that border or overlap USACE and NOAA surveys. NOAA offices that collect or maintain coastal zone inland bathymetry include the NOAA Estuarine Bathymetry, Raster Nautical Charts, Integrated Model of Coastal Relief DEM, Inland Electronic Navigation Charts, Maintained Channels, and NOAA Digital Coast Data programs (appendix 3). 
Surveys completed by the USACE for the Columbia River, Mississippi River, and Ohio River Community projects include inland lake or river-channel bathymetry for hundreds of miles of reaches trending inland from the coast. Other USACE navigation projects cover waterway channels, harbor areas, breakwaters, and other coastal features (Byrnes and others, 2002). Surveys can be accessed at each USACE district office Web site though estuarine bathymetry, Inland Electronic Navigation Chart surveys (U.S. Army Corps of Engineers, 2014a), and other survey program data are also transferred to the NOAA and are available at several NOAA Web sites (appendix 3). Horizontal accuracy standards for hydrography surveys completed for hard and soft bottom materials can range from 2 to $5 \mathrm{~m}+5$ percent of depth for depths up to $100 \mathrm{~m}$. In deeper water (100 to $150 \mathrm{~m}$ ), accuracy is $20 \mathrm{~m}+5$ percent of depth. Depth accuracies are calculated based on a constant depth error, a depth-dependent error, and actual depth and should meet the horizontal accuracy standards for hard and soft bottom materials (U.S. Army Corps of Engineers, 2002). Accuracy standards for mechanical or acoustic survey systems are more rigid, varying between \pm 0.25 to $\pm 2.00 \mathrm{ft}$ ( \pm 0.076 to $\pm 0.609 \mathrm{~m}$ ) (Byrnes and others, 2002).

The USACE HEC completes RAS modeling to provide bathymetry for ports including bays or the mouths and coastal channels of rivers (U.S. Army Corps of Engineers, 2014e). The HEC-RAS provides four one-dimensional river analysis components and graphics that include river-system schematics, cross sections, profiles, and other features including a 3D plot of multiple cross sections. Each HEC-RAS project requires geometry data (and flow and plan data) that consist of a description of the size, shape, and connectivity of stream cross sections. Although the primary application is for modeling one-dimensional steady flow, elements of the program, specifically cross sections and geometric data, can provide bathymetry for the inland to shoreline zone that may be appropriate for integration in the 3DEP or as a useful referenced source. The bathymetry data might also provide control points for evaluating and planning new data acquisition or for new bathymetry surveys. Alternatively, in keeping with the USGS National Map efforts to collaborate with Federal, state, and local partners to improve and deliver topographic information (U.S. Geological Survey, 2014a), the data source might be shared.

The Ohio River Community project is a USACE HECRAS program that began in 2006, in cooperation with the National Weather Service (NWS), Ohio River Forecast Center, and the USGS to develop a community unsteady flow model for the main stem of the Ohio River and major tributaries that includes 1,300 $\mathrm{mi}(2,092 \mathrm{~km})$ of bathymetry (Adams and others, 2010). Lidar data collection was completed by the USACE Memphis District, Pennsylvania Spatial Data Access, and the Ohio Geospatial Referenced Information System. The USACE developed bathymetry data and more than 2,800 cross sections for 11 river channels extending through Pennsylvania, Kentucky Missouri, Ohio, and Tennessee (Adams and others, 2010). In late September 2014, personnel from the USACE Operations Division completing hydrographic surveys for developing inland bathymetry indicated a new USACE eHydro program was underway to develop and distribute Ohio River Community HEC-RAS survey products (Brian Tetreault, U.S. Army Corps of Engineers, written commun., 2014). The eHydro program is in initial planning stages and not fully setup to deliver online data as of 2016, but the USACE anticipates providing sample data in the future, and the USGS is encouraged to keep in contact.

The Columbia River project (U.S. Army Corps of Engineers, 2014b) includes main stem and tributary bathymetry, with about $146 \mathrm{mi}(235 \mathrm{~km})$ of channel-line surveys and crossline survey data for the river course where it reaches inland from the mouth of the river west of Astoria, Oregon, to the Vancouver Turning Basin, Oregon. The USACE-maintained channel bathymetry data (appendix 2) with depths represented as polygonal sections are also available for the Columbia River. These USACE hydrographic surveys are typically completed to provide maps at a scale of 1:2,500 with highresolution detail and are available from the NOAA (National Oceanic and Atmospheric Administration, Office of Coastal Survey, 2014). In a discussion about the Columbia River project, the USACE Portland District office personnel responsible for building the Columbia River model have offered to provide the survey data if the 3DEP moves forward with an inland bathymetry program (Brian Tetreault, U.S. Army Corps of Engineers, written commun., September 26, 2014; Jason McDonald, U.S. Army Corps of Engineers, written commun., January 5, 2016). Maintained channel bathymetry is also available for the Willamette River from the confluence with the Columbia River to the Broadway Bridge at Portland, Oregon. Data are in text, shapefile, and portable document formats.

\section{Framework for a Baseline Inland Bathymetry Program}

Baseline inland bathymetry and topobathymetry provide a reference frame for evaluating water resources relative to atrisk or projected demands or modeling that may be related to population growth, land use, energy needs, ecological systems, or floodplain management. Inland bathymetry also can provide a real-time metric for correlating trends in climate relative to temporal and spatial temperature changes that affect precipitation, evapotranspiration, and runoff (Wang and Hejazi, 2011).

Acquired survey data and products derived from integration of inland bathymetric surveys would need to meet applicable standards for geospatial data and metadata (USGS National Mapping Standards) and, as appropriate, USGS lidar base specifications (Heidemann, 2014). To be accessible and useful to the broad spectrum of potential Federal, state, and non-government users; the 3DEP inland bathymetry program would comply with hydrographic feature nomenclature that aligns with the Federal Geographic Data Committee (FGDC) National Hydrography Data Content Standard for Coastal 
and Inland Waterways (Federal Geographic Data Committee, 2008), and adheres to the Spatial Data Transfer Standard geospatial data model (U.S. Geological Survey, 2014b), information and system models, and the Geographic Names Information System (Federal Geographic Data Committee, 2008). As a first approach, a program level of effort estimate could consider project personnel for planning and completing, processing, and publishing bathymetry data; and resources for acquisition and processing existing survey data.

\section{Integration of Existing Bathymetry Surveys}

Inland bathymetric survey reports were reviewed, and those projects that provided readily available datasets were compiled and assessed to help determine the utility and feasibility for developing a mainland inland bathymetry dataset in the 3DEP (appendix 2). Based on the available bathymetry data collected using different survey techniques, developing a program for incorporating inland bathymetry into the 3DEP will require software and methods such as described in this report to integrate bathymetry or topobathymetry data from various sources and in several formats with topographic DEMs in the 3DEP.

Across the United States, most of the discovered surveys for which datasets are available and in a format compatible with the 3DEP have been completed by the USGS, with the most complete coverage of river and lake surveys available in the Midwest region (fig. 2). A comparison between the distribution of reported surveys and primary rivers depicted in The National Map hydrography image (fig. 3) highlights the paucity of bathymetric surveys for river systems in the United States. Although the lack of surveys might be attributed to survey project data that were not discovered or inadvertently overlooked, it is also possible that there are surveys sponsored by private entities or surveys completed on Tribal lands or classified as proprietary, which are not currently available for distribution. The results of the survey collection effort presented herein, however, are representative of completed surveys and are used to help guide recommendations for a 3DEP pilot bathymetry project.

\section{Recommendations for Inland Bathymetry Surveys}

A regional perspective for developing new bathymetric survey targets is guided by evaluation of primary rivers crossing the United States for which survey data were not compiled but that can be critical to population center water supplies; flood hazard mapping; agricultural enterprises; health and preservation of wildlife habitat, forest, and rangeland; and possibly energy or economic interests. These long rivers course through various physiographic regions under various site conditions and topography that are controlled by natural physical processes and human-made factors, which may have a bearing on the priority for proposed bathymetry survey programs. In addition to providing water feature geometries important to hydrologic and hydraulic analyses or modeling, reaches along each river can provide important bathymetry data and survey parameters important to evolving lidar-based inland bathymetry survey strategies for collection and analysis.

\section{U.S. Midcontinent.-}

- The Platte River, a tributary of the Missouri River, begins at the eastern Nebraska State line. The Platte River trends east-west through Kansas, and from there it continues to the Front Range (not shown) as the North and South Platte Rivers (fig. 2).

- The Arkansas River, a primary tributary of the Mississippi River, begins in Colorado and trends through Kansas and Oklahoma (1,469 mi; 2,364 km) through major metropolitan communities (fig. 3).

- The Colorado River begins in the central Rocky Mountains (not shown) and flows through the southwestern United States to eventually empty into the Gulf of California (fig. 3). The Colorado River is a primary water resource for all traversed states, has been developed under Federal oversight, and supports hydraulic projects such as the Hoover Dam and Glen Canyon Dam, so that bathymetric surfaces may represent artificial elevations.

Northwest United States.-

- The Snake River is a primary river in the Northwest and is a tributary of the Columbia River (fig. 2). Beginning in western Wyoming, the river trends westerly across southern Idaho and eventually empties in the cities of Richland, Kennewick, and Pasco, Washington (not shown). As previously noted, bathymetric data collected in the USACE HEC-RAS modeling program delineates Columbia River depths that could be useful in developing plans for the Snake River. The USACE Portland District office was contacted and indicates survey data can be shared if the 3DEP implements the inland bathymetry project to include existing acquired data.

Pacific United States.-

- The Sacramento River (fig. 2) is a primary river of northern California. The headwaters are in the Klamath Mountains (not shown) and from there the river runs southward into central California emptying into the Sacramento-San Joaquin River Delta and San Francisco Bay. The river is wide, deep, and muddy in some places.

\section{Southeast United States.-}

- Numerous rivers flow southeasterly and south-southwesterly across the Coastal Plains region to reach the Atlantic Coast or the Gulf of Mexico. The largest are the James River (Virginia), Roanoke River (North Carolina), Savannah River (South Carolina), and 


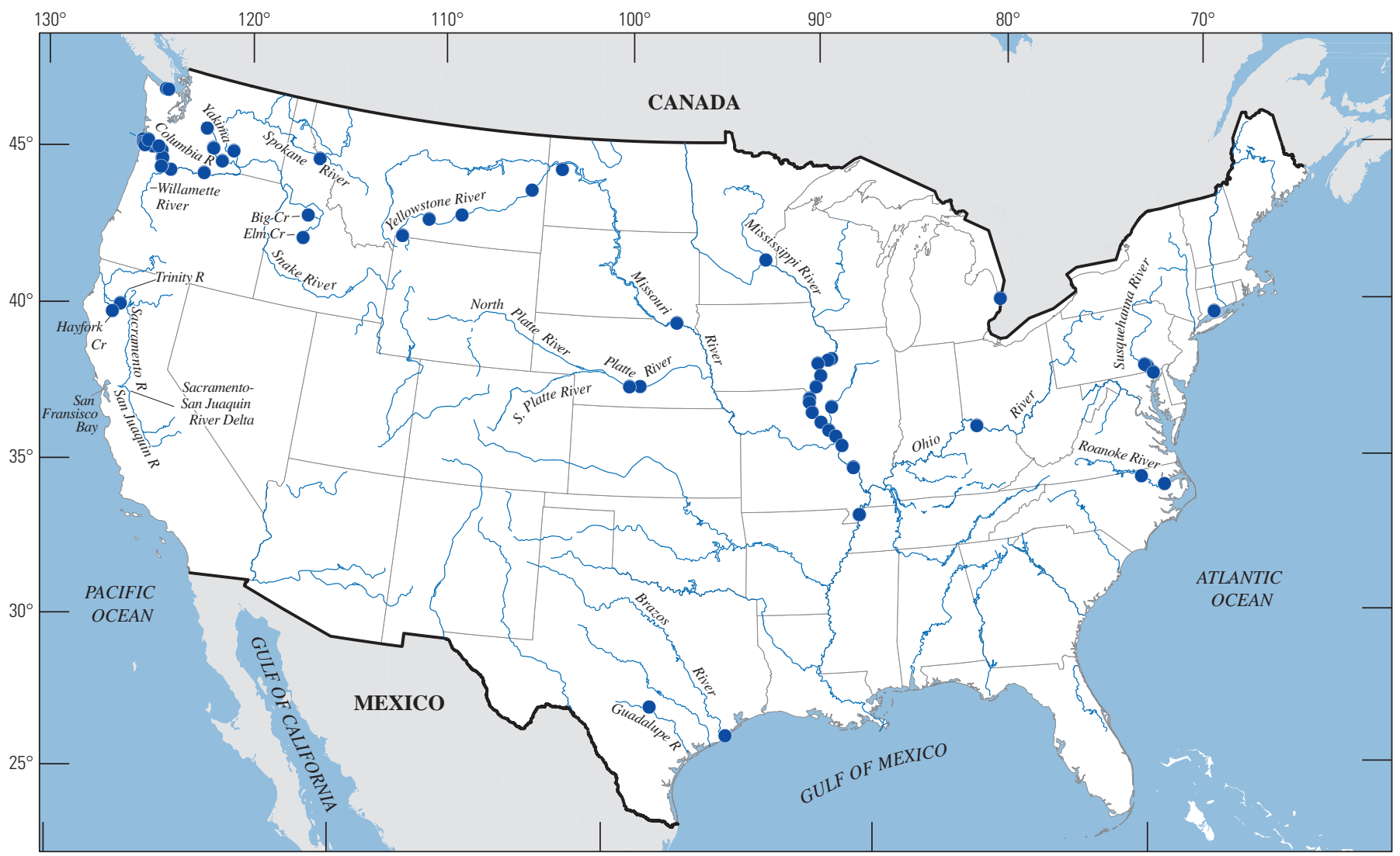

Base from U.S. Geological Survey digital data Albers Equal-Area Conic projection North American Daturm of 1983

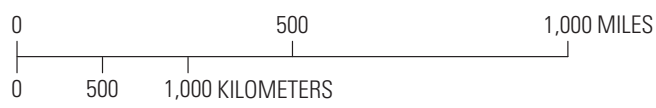

EXPLANATION

- Inland bathymetry survey location

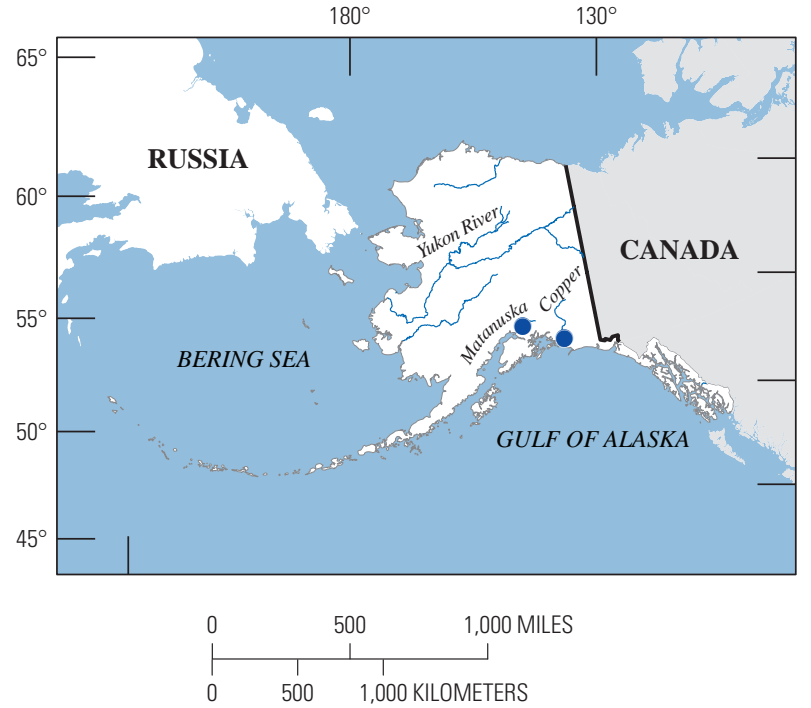

Figure 2. Distribution of collected inland bathymetry surveys for the conterminous United States and Alaska. 


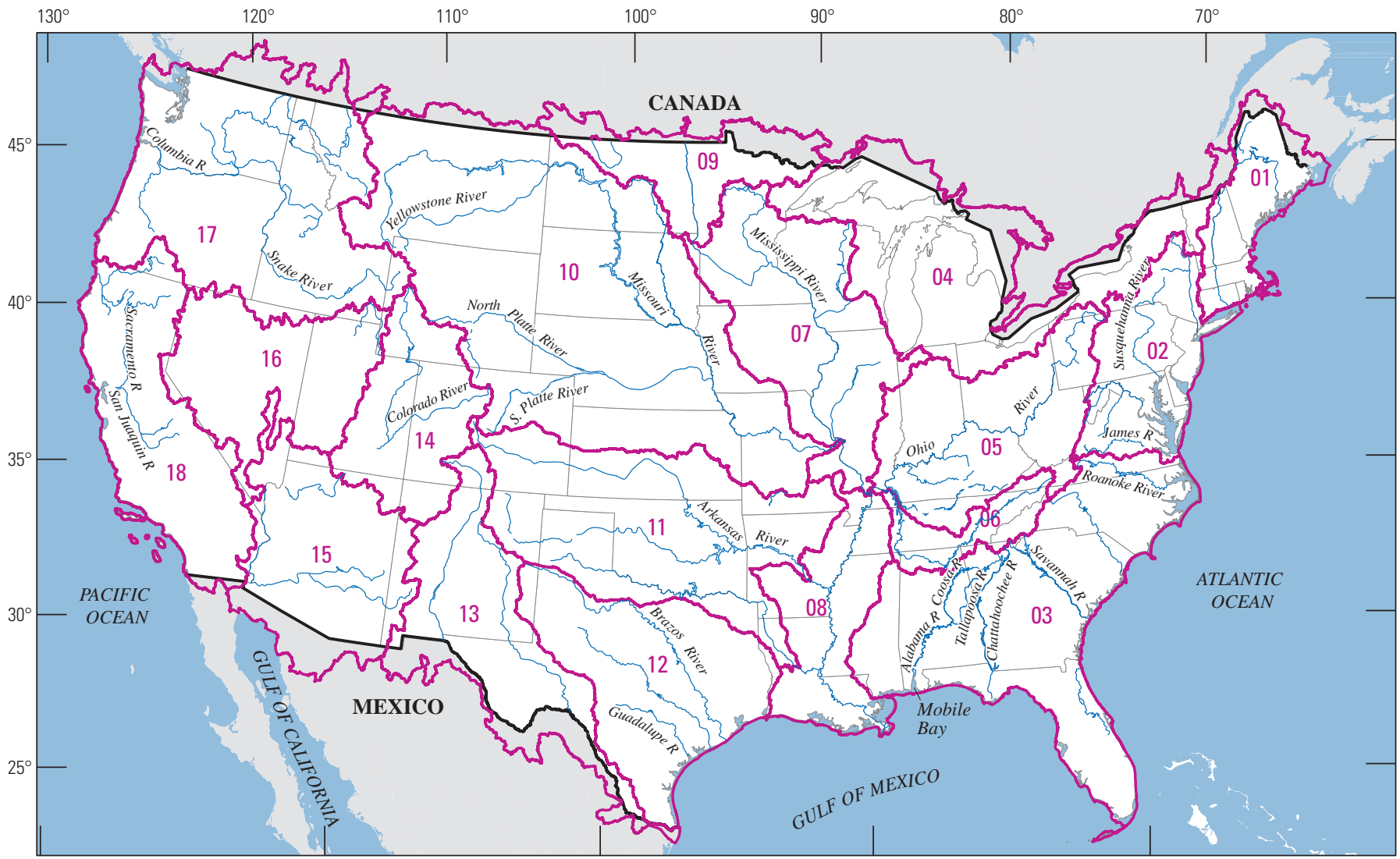

Base from U.S. Geological Survey digital data Albers Equal-Area Conic projection North American Daturm of 1983

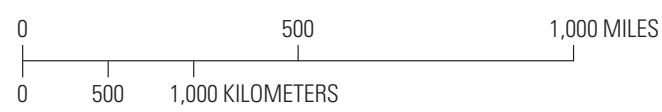

\section{EXPLANATION}

10 National Watershed Boundary Dataset two-digit hydrologic unit boundary

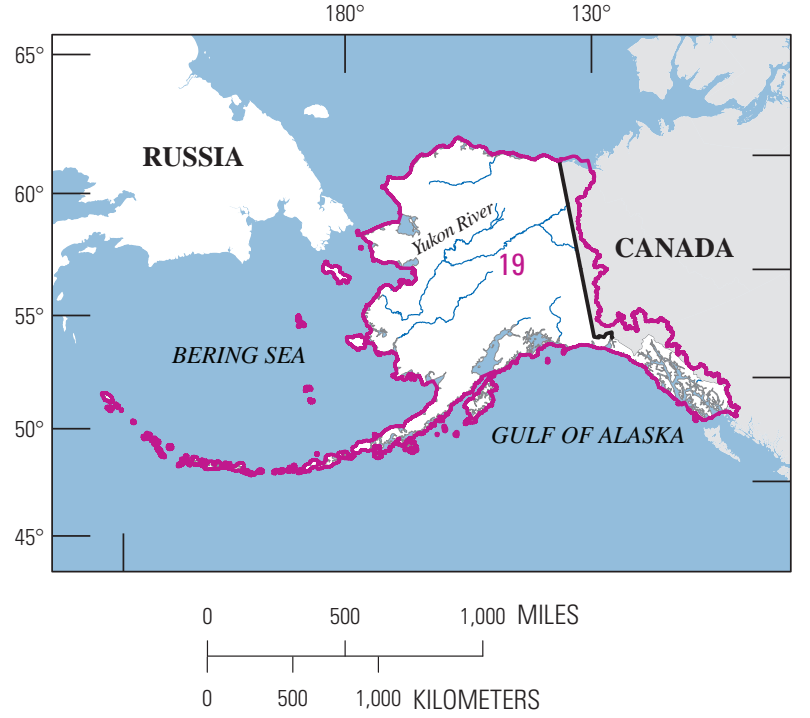

Figure 3. Distribution of primary river systems for the conterminous United States and Alaska. 
Chattahoochee River (forming the border between Georgia and Alabama). Crosscutting this trend, the Alabama River runs northeast-southwest from the confluence of the Tallapoosa and Coosa Rivers to Mobile Bay, Alabama (fig. 3). Understanding the nature of channel configurations and changes in this region can be critical to mapping and planning for flood disasters.

Statistical analysis of water use in 2005 (U.S. Census Bureau, 2005) indicated that thermoelectric power facilities used 41 percent, irrigation or agricultural entities used 31 percent, and domestic water use accounted for 8 percent (fig. 4). With regard to population demands, the U.S. Environmental Protection Agency (2104) depicted the distribution of domestic water use and the projected population growth in the United States by State indicating that Idaho, Nevada, and Utah are the biggest water users, and that all but Wyoming are attributed with some of the highest estimated growth in population (fig. 4).

Based on a preliminary overview of demands and using a more local approach, a correlation of U.S population growth projected by the U.S. Census Bureau (fig. 4) and the distribution of primary river courses not surveyed (figs. 2 and 3 ) are suggested as rudimentary criteria to use to prioritize rivers for a bathymetric survey program. In line with the first assessment, the Colorado River, which traverses Colorado, Utah, Arizona and California, is ranked as a high priority for bathymetry acquisition; the Sacramento River, which provides freshwater to the highly populated central and southern California areas also is ranked with a high priority. Population growth in Idaho and Oregon suggests rivers in these States also be given high priority. Water use in the eastern United States is less than in the western United States; however, based on the population growth distribution, North Carolina, South Carolina, and Georgia are expected to have the largest percentage increase, and so further analysis of needs and supplies in these States may identify priority rivers that should be included in a proposal for inland bathymetry.

The late 2015 and early 2016 flooding along the Mississippi River serves as a reminder that bathymetric mapping is important for developing or updating flood zone mapping and developing flood plain analysis.
United States freshwater withdrawals, 2005

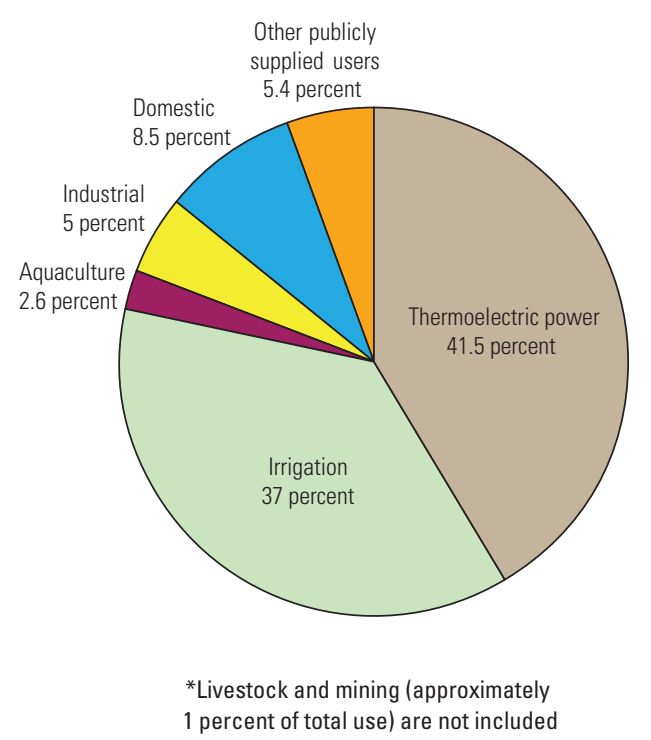

Domestic water use and projected population change by 2030

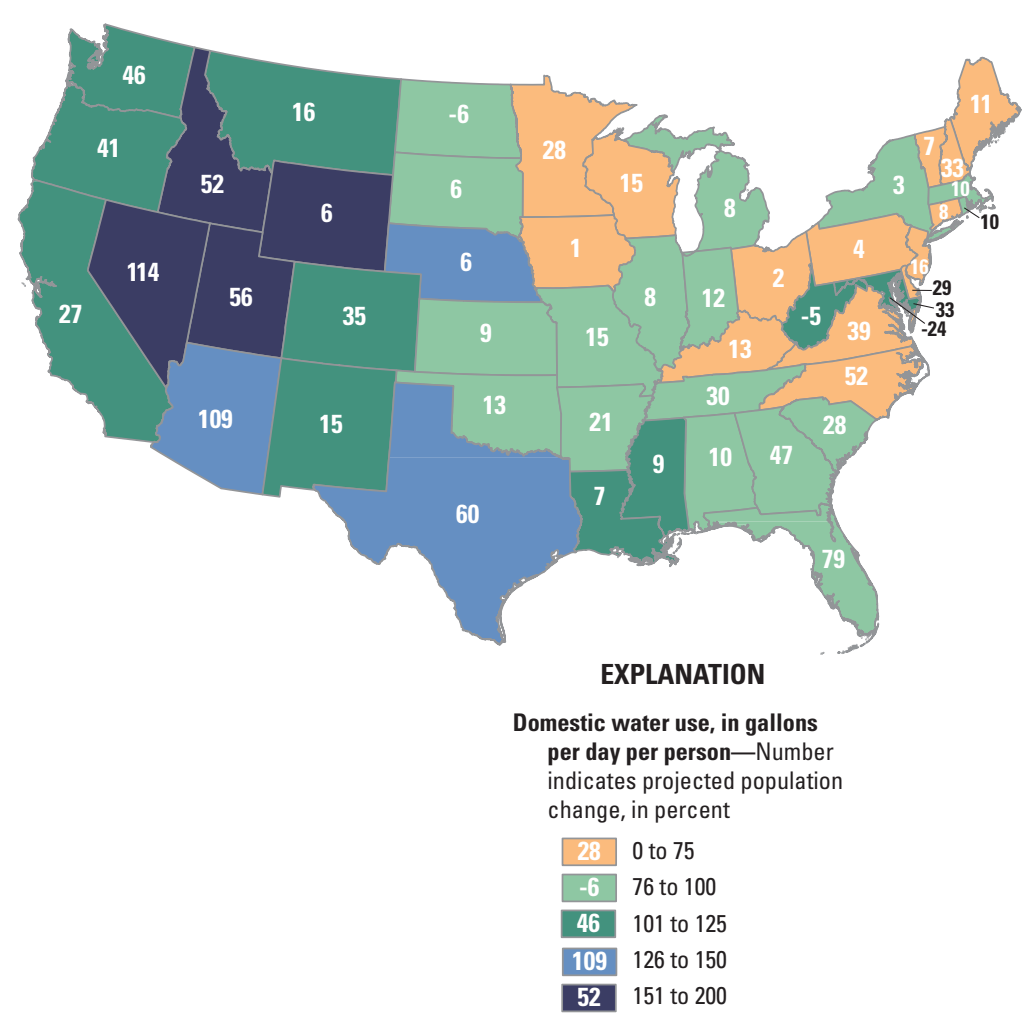

Figure 4. Total freshwater withdrawals and projected domestic water use. 


\section{Summary}

Standard methods for collecting bathymetry data use wading, acoustic, light detection and ranging (lidar) or any combination of these three survey methods; acoustic survey programs are the most common. The combined surface area and total length measures of compiled bathymetry survey sources discovered for the United States is about 136,345 acres (213 square miles; 552 square kilometers) and more than 5,100 miles (8,208 kilometers), respectively. These totals are based on identifying inland bathymetry surveys for which data were readily available; however, new sources and sources for previously discovered surveys for which data were not readily available could be further investigated and possibly provide additional bathymetry data for integration in the 3D Elevation Program (3DEP).

Compiled inland bathymetry surveys using one or more of the three described data collection methods are primarily from the U.S. Geological Survey. Some of these investigations include survey program data that can provide metrics for evaluating site conditions and system parameters that constrain or limit data collection that can be used to guide planning for new surveys. The National Oceanic and Atmospheric Administration and U.S. Army Corps of Engineers provide important acoustic and lidar surveys for some intertidal to offshore zones that can include river channels, bays, and estuaries. Results of these coastal-to-inland surveys can provide inland to offshore bathymetry data that are important to fresh water resource management, and could be acquired for integration in a bathymetry data baseline. These surveys also could be used to guide future bathymetry data acquisition programs. The best choice for a survey technique will depend on data needs and site conditions. For some conditions, all methods can be required for developing bathymetry and topobathymetry without gaps or over interpolation.

Integration of lidar-derived bathymetric data in the 3DEP supports the National Geospatial Program goal to systematically collect enhanced elevation data in the form of high-resolution lidar data (U.S. Geological Survey, 2014a). Specific to hydrography, a 3DEP inland bathymetry program can provide the U.S. Geological Survey National Hydrography Dataset program a source for improved river and waterbody geometries important to hydrologic and hydraulic analyses and modeling by scientists and engineers.

Techniques for collecting and processing inland bathymetry lidar surveys are evolving and a better understanding of the advantages or disadvantages associated with using these surveys will help ensure a successful bathymetry survey program. Planning a survey program that includes systematically acquiring survey metrics for data collection and processing steps will help effectively direct resources and contribute to developing an optimal inland bathymetry program.

In order to further study techniques for collecting and developing lidar-derived bathymetry data and for integrating inland bathymetric lidar data with topographic data, a pilot study using the following criteria for selecting one or more project areas is recommended. The first criterion is to select one or more areas where rivers provide primary water supplies for communities, agriculture, energy, and ecological systems, and include rivers that cross variable physiographic regions. Critical to planning for and completing successful bathymetric surveys, lidar data collections completed in variable physiography will provide geomorphology and other site parameter data that can be recorded and assessed to enhance understanding for optimal conditions or drawbacks impacting survey results. A second criterion focuses on future water resource needs based on projected population growth across the United States. Initially, proposed surveys include the following:

- the Colorado River traversing Colorado, Utah, Arizona and California;

- the Sacramento River in central and southern California;

- the Salmon River and Snake River in Idaho; and

- the Snake River and Columbia River in Oregon.

A 3DEP inland bathymetry survey program can provide baseline river and waterbody geometries needed for hydraulic and hydrologic analyses or numerical modeling that are central to water resource budgeting, water-quality monitoring, remediation programs, dam and reservoir projects, floodplain mapping, and other water resource oversight and management concerns. Decisions for directing a new inland bathymetry data collection program may be guided by an evaluation of needs and site conditions to make best use of resources and to ensure data are collected and processed to produce quality bathymetry. Better knowledge of site condition limitations to ensure use of optimal techniques for successful surveys in different physiographic regions is still needed. There is probably no one solution for all survey requirements and conditions, which will be important to remember when developing options and strategies for implementing an inland bathymetry data survey program in the 3DEP.

\section{References Cited}

Adams, Thomas; Chen, Sherry; Davis, Raymond; Schade, Trent; and Lee, Deborah, 2010, The Ohio River Community HEC-RAS model: American Society of Civil Engineers, World Environmental and Water Resources Congress 2010, accessed June 4, 2016, at http://ascelibrary.org/doi/ abs/10.1061/41114\%28371\%29160.

Allouis, Tristan; Bailly, Jean-Stéphane; and Feurer, Denis, 2007, Assessing water surface effects on LiDAR bathymetry measurements in very shallow rivers-A theoretical study: European Space Agency, Space for Hydrology Workshop, 2nd, Geneva, Switzerland, November, 12-14, 2007, 8 p. [Also available at http://earth.esa.int/hydrospace07/ participants/07_14/07_14_Allouis.pdf.] 
American Society for Photogrammetry and Remote Sensing, 2014a, ASPRS lidar guidelines-Horizontal accuracy reporting: American Society for Photogrammetry and Remote Sensing, accessed September 4, 2014, at http:// www.asprs.org/a/society/committees/standards/Horizontal_Accuracy_Reporting_for_Lidar_Data.pdf.

American Society for Photogrammetry and Remote Sensing, 2014b, ASPRS positional accuracy standards for digital geospatial data-Edition 1, version 1: American Society for Photogrammetry and Remote Sensing, 39 p., accessed September 4, 2014, at http://www.asprs.org/PAD-Division/ Asprs-Positional-Accuracy-Standards-For-Digital-Geospatial-Data.html.

Bergen, W.A., and Sanders, Pat, 2013, USACE/IHO Survey specifications workshop: The Hydrographic Society of America Conference, New Orleans, La., March 25, 2013, 47 p., accessed June 26, 2015, at http://www.thsoa.org/ pdf/IHO\%20and\%20USACE\%20Hydrographic\%20Standards\%202.pdf.

Bresina, Larry, 2011, Observations on Secchi depth measurement variability-A report to the Wisconsin Department of Natural Resources: The Aquatic and Terrestrial Resources Inventory, 18 p., accessed September 16, 2014, at http:// wiatri.net/cbm//Partnership/Posters/2010/SecchiMeasurementReport.pdf.

Brissette, M.B., and Clarke, J.E., 2001, Side scan versus multibeam Echosounder object detection-A comparative analysis: Mosaic Hydro, 11 p., accessed June 26, 2015, at http://www.mosaichydro.com/sites/default/files/papers/sidescan_vs_mbes.pdf.

Brunner, Gary, 2013, Advances in hydrologic engineeringUnsteady flow hydraulic model of the lower Columbia River system: U.S. Army Corps of Engineers, Hydrologic Engineering Center, 13 p. [Also available at http://www.hec. usace.army.mil/newsletters/HEC_Newsletter_Spring2013. pdf.]

Byrnes, M.R., Baker, J.L., and Li, Feng, 2002, Quantifying potential measurement errors and uncertainties associated with bathymetric change analysis: U.S. Army Corps of Engineers, Coastal and Hydraulics Laboratory, Coastal and Hydraulics Engineering Technical Notes, ERDC/CHL CHETN-IV-50, accessed August 7, 2014, at http://acwc. sdp.sirsi.net/client/search/asset/1000409.

Carter, Jamie; Schmid, Keil; Waters, Kirk; Betzhold, Lindy; Hadley, Brian; Mataosky, Rebecca; Helleran, Jennifer; and National Oceanic and Atmospheric Administration Coastal Services Center, 2012, Lidar 101-An introduction to lidar technology, data, and applications: Charleston, S.C., National Oceanic and Atmospheric Administration Coastal Services Center, 72 p. [Also available at https://coast.noaa. gov/data/digitalcoast/pdf/lidar-101.pdf.]
Dharmapuri, S.S., 2013, Automated methods-Using lidar data for breakline validation: LiDAR Magazine, v. 3, no. 5, 4 p., accessed January 31, 2014, at http://www.lidarmag. com/PDF/LiDARMagazine_DharmapuriAkl-AutomatedBreaklineValidation_Vol3No5.pdf.

Federal Geographic Data Committee, 2000, National hydrography data content standard for coastal and inland watersPublic review draft: Federal Geographic Data Committee, accessed September 17, 2014, at https://www.fgdc.gov/standards/projects/FGDC-standards-projects/coastal-and-inlandwaterways/standards/projects/FGDC-standards-projects/ coastal-and-inland-waterways/HydroStd_pr_draft.pdf.

Federal Highway Administration, 2006, Assessing stream channel stability at bridges in physiographic regions: U.S. Department of Transportation, Federal Highway Administration, Publication No. FHWA-HRT-05-072, accessed September 15, 2015, at https://www.fhwa.dot.gov/publications/research/infrastructure/hydraulics/05072/05072.pdf.

Federal Geographic Data Committee, 2008, Geographic information framework data content standard-Part 7E-Transportation-Inland waters: Federal Geographic Data Committee, FGDC-STD-014.7e-2008, accessed September 17, 2014, at https://www.fgdc.gov/standards/projects/FGDCstandards-projects/framework-data-standard/GI_FrameworkDataStandard_Part7e_Transportation_Waterways.pdf.

Feurer, Denis; Bailly, Jean-Stéphane; Puech, Christian; Le Coarer, Yann; and Viau, A.A., 2008, Very-high-resolution mapping of river-immersed topography by remote sensing: Progress in Physical Geography, v. 32, no. 4, p. 403-419, accessed September 3, 2014, at http://dx.doi. org/10.1177/0309133308096030.

Giardino, J.R., and Lee, A.A., 2011, Rates of channel migration on the Brazos River: College Station, Tex., Texas A\&M University, Department of Geology and Geophysics, 121 p., accessed November 7, 2014, at https://www.twdb.texas.gov/ publications/reports/contracted_reports/doc/0904830898_ Brazos.pdf.

Government of Canada, Fisheries and Oceans Canada, 2014, Using lasers to measure depths and heights: Government of Canada, Fisheries and Oceans Canada, accessed August 28, 2014, at http://www.dfo-mpo.gc.ca/science/hydrographyhydrographie/lasers-eng.html.

Graf, W.L., 2006, Downstream hydrologic and geomorphic effects of large dams on American rivers: Geomorphology, v. 79, no. 3-4, p. 336-360. [Also available at http://dx.doi. org/10.1016/j.geomorph.2006.06.022.]

Graham, Lewis, 2012, Breaklines and lidar data: Photogrammetric Engineering \& Remote Sensing, accessed March 20, 2015, at ftp://lidar.dnr.state.mn.us/documentation/ Breaklines\%20and\%20Lidar\%20Data\%20PE\&RS\%20 March2012.pdf. 
Heidemann, H.K., 2014, Lidar base specification (v. 1.2, November 2014): U.S. Geological Survey Techniques and Methods, book 11, chap. B4, 67 p. with appendixes. [Also available at http://dx.doi.org/10.3133/tm11B4.]

Hilldale, R.C., and Raff, David, 2008, Assessing the ability of airborne lidar to map river bathymetry: Earth Surface Processes and Landforms, v. 33, no. 5, p. 773-783. [Also available at http://dx.doi.org/10.1002/esp.1575.]

Hohenthal, Johanna; Alho, Petteri; Hyyppa, Juha; and Hyyppa, Hannu, 2011, Laser scanning applications in fluvial studies: Progress in Physical Geography, v. 35, no. 6, p. 782-809, accessed January 15, 2015, at http://dx.doi. org/10.1177/0309133311414605.

International Hydrography Organization, 2004, BSBTest data set: International Hydrography Organization, accessed October 12, 2014, at http://www.iho.int/iho_pubs/ standard/S-64/RNC_Test_Data_Sets/BSB_TDS/BSB_TDS. htm.

Juracek, K.E., 2001, Channel-bed elevation changes downstream from large reservoirs in Kansas: U.S. Geological Survey Water-Resources Investigation Report 01-4205, 24 p. [Also available at http://ks.water.usgs.gov/pubs/reports/ wrir.01-4205.html.]

Kenny, A.J., Cato, I., Desprez, M., Fader, G., Schuttenhelm, R.T.E., and Side, J., 2003, An overview of seabed-mapping technologies in the context of marine habitat classification: ICES Journal of Marine Science, v. 60, no. 2, p. 411-418. [Also available at http://dx.doi.org/10.1016/S10543139(03)00006-7.]

Kinzel, P.J., Legleiter, C.J., and Nelson, J.M., 2013, Mapping river bathymetry and a small footprint green lidar: applications and challenges: Journal of the American Water Resources Association, v. 49, no. 1, p. 183-204. [Also available at http://dx.doi.org/10.1111/jawr.12008.]

Kinzel, P.J., Wright, C.W., Nelson, J.M., and Burman, A.R., 2007, Evaluation of an experimental lidar for surveying a shallow, braided, sand-bedded river: Journal of Hydraulic Engineering, v. 133, no. 7, p. 838-842. [Also available at http://dx.doi.org/10.1061/(ASCE)07339429(2007)133:7(838).]

Krasovskaia, Irina, 1995, Quantification of the stability of river flow regimes: Hydrological Sciences Journal, v. 40, no. 5, p. 587-589, accessed January 24, 2014, at http:// dx.doi.org/10.1080/02626669509491446.

Langland, M.J., 2009, Bathymetry and sediment-storage capacity change in three reservoirs on the lower Susquehanna River, 1996-2008: U.S. Geological Survey Scientific Investigations Report 2009-5110, 21 p. [Also available at http://pubs.usgs.gov/sir/2009/5110/.]
Legleiter, C.J., and Kyriakidis, P.C., 2007, Spatial prediction of river channel topography by kriging: Earth Surface Processes and Landforms, v. 33, no. 6, p. 841-867. [Also available at http://dx.doi.org/10.1002/esp.1579.]

Leopold, L.B., and Maddock, Thomas, Jr., 1953, The hydraulic geometry of stream channels and some physiographic implications, U.S. Geological Survey Professional Paper 252, 57 p. [Also available at http://pubs.er.usgs.gov/publication/pp252.]

Linhart, S.M., and Lund, K.D., 2008, Bathymetric contour maps of lakes surveyed in Iowa in 2005: U.S. Geological Survey Scientific Investigations Map 3037, 7 sheets. [Also available at http://pubs.usgs.gov/sim/3037/.]

McKean, Jim; Nagel, Dave; Tonina, Daniele; Bailey, Philip; Wright, C.W.; Bohn, Carolyn; and Nayeghandi, Amar, 2009, Remote sensing of channels and riparian zones with a narrow-beam aquatic-terrestrial lidar: Remote Sensing, v. 1, no. 4, p. 1065-1096. [Also available at http://dx.doi. org/10.3390/rs1041065.]

Manitoba Water Stewardship and Manitoba Health, 2011, Turbidity in Manitoba water supplies: Manitoba Water Stewardship and Manitoba Health, accessed September 15, 2014, at http://www.gov.mb.ca/waterstewardship/odw/public-info/ fact_sheets/pdf/factsheet_turbidity.pdf.

Maune, David, 2011, Frequently asked questions (FAQs), appendix A of Elevation: Tennessee Department of Finance and Administration, accessed January 5, 2014, at http:// www.tn.gov/assets/entities/finance/oir/attachments/LiDAR_ Frequently_Asked_Questions.pdf.

Meade, M.E., 2008, From the ground up-Collecting breaklines: Point of Beginning, accessed January 27, 2015, at http://www.pobonline.com/articles/91977-from-the-groundup-collecting-breaklines.

Merwade, V.M., Maidment, D.R., and Goff, J.A., 2006, Anisotropic considerations while interpolating river channel bathymetry, Journal of Hydrology, v. 331, no. 3-4, p. 731-741. [Also available at http://dx.doi.org/10.1016/j. jhydrol.2006.06.018.]

Merwade, V.M., Cook, Aaron, and Coonrod, Julie, 2008, GIS techniques for creating river terrain models for hydrodynamic modeling and flood inundation mapping: Environmental Modelling \& Software, v. 23, no. 10-11, p. 1300-1311. [Also available at http://dx.doi.org/10.1016/j. envsoft.2008.03.005.]

Montana State Library, 2005, Yellowstone River corridor clearinghouse-Elevation data: Montana State Library, Montana Geographic Information Clearinghouse, accessed August 8, 2014, at http://geoinfo.msl.mt.gov/Home/data/ yellowstone_river_corridor_resource_clearinghouse/elevation_data.aspx. 
Mossa, Joann, and Coley, David, 2015, Planform change rates in rivers with and without in stream and floodplain sand and gravel mining-Assessing instability in the Pascagoula River and tributaries, Mississippi: Gainesville, Fla., University of Florida, Department of Geography, accessed January 8, 2014, at http://minerals.er.usgs.gov/mrerp/reports/Mossa04HQGR0178/Mossa_Report2-04HQGR0178.pdf.

National Oceanic and Atmospheric Administration, 2012, Hydrographic survey techniques-Multibeam sonar: National Oceanic and Atmospheric Administration, accessed June 26, 2015, at http://celebrating200years.noaa. gov/breakthroughs/hydro_survey/welcome.html\#sonar.

National Oceanic and Atmospheric Administration, Coastal Services Center, 2014, Digital coast: National Oceanic and Atmospheric Administration, Office for Coastal Management, Digital Coast Web site, accessed September 17, 2015, at http://coast.noaa.gov/digitalcoast/.

National Oceanic and Atmospheric Administration, National Geophysical Data Center, 2014a, NOAA VDatum digital elevation model (DEM) project: National Oceanic and Atmospheric Administration, National Geophysical Data Center, accessed June 24, 2015, at http://www.ngdc.noaa. gov/mgg/inundation/vdatum/vdatum.html.

National Oceanic and Atmospheric Administration, National Geophysical Data Center, 2014b, Great Lakes bathymetry: National Oceanic and Atmospheric Administration, National Geospatial Data Center, accessed September 15, 2015, at https://www.ngdc.noaa.gov/mgg/greatlakes.

National Oceanic and Atmospheric Administration, National Geophysical Data Center, 2014c, Integrated models of coastal relief: National Oceanic and Atmospheric Administration, National Geophysical Data Center, accessed October 4, 2014, at http://www.ngdc.noaa.gov/mgg/coastal/.

National Oceanic and Atmospheric Administration, National Geophysical Data Center, 2014d, Digital elevation model (DEM) discovery portal: National Oceanic and Atmospheric Administration, National Geophysical Data Center, accessed October 14, 2014, at http://www.ngdc.noaa.gov/ mgg/dem/demportal.html.

National Oceanic and Atmospheric Administration, National Ocean Service, 2015, NOS hydrographic surveys specifications and deliverables: Silver Spring, Md., U.S. Department of Commerce, 128 p., accessed September 17, 2015, at http://www.nauticalcharts.noaa.gov/hsd/specs/Specs_2015. pdf.

National Oceanic and Atmospheric Administration, National Ocean Service, 2014, Data explorer: National Oceanic and Atmospheric Administration, National Ocean Service, accessed October 10, 2014, at http://oceanservice.noaa.gov/ dataexplorer/.
National Oceanic and Atmospheric Administration, National Ocean Service, 2015, What is bathymetry?: National Oceanic and Atmospheric Administration, National Ocean Service, accessed June 24, 2015, at http://oceanservice. noaa.gov/facts/bathymetry.html.

National Oceanic and Atmospheric Administration, Office of Coast Survey, 2015, Side scan sonar: National Oceanic and Atmospheric Administration, Office of Coast Survey, accessed June 25, 2015, at http://www.nauticalcharts.noaa. gov/hsd/SSS.html.

National Oceanic and Atmospheric Administration, Office of Coastal Survey, 2013, Maintained channels in US waters: National Oceanic and Atmospheric Administration, Office of Coastal Survey, accessed September 9, 2014, at http:// coast.noaa.gov/arcgis/rest/services/MarineCadastre/NavigationAndMarineTransportation/MapServer.

National Oceanic and Atmospheric Administration, Office of Coastal Survey, 2014, Electronic charts (ENC): National Oceanic and Atmospheric Administration, Office of Coastal Survey, accessed August 17, 2014, at http://www.charts. noaa.gov/InteractiveCatalog/nrnc.shtml.

National Park Service, 2009, Comparison of shallow water mapping technologies: National Park Service, accessed August 17, 2014, at https://www.nps.gov/caco/ShallowWater-Mapping-Techniques-Workshop.htm.

Richards, J.M., 2013, Bathymetric surveys of selected lakes in Missouri-2000-2008: U.S. Geological Survey Open-File Report 2013-1101, 9 p. [Also available at http://pubs.usgs. gov/of/2013/1101.]

Rogala, James, 2013, Status of completed pools, U.S. Geological Survey Upper Midwest Environmental Sciences Center, Accessed June 24, 2014, at http://www.umesc.usgs.gov/ aquatic/bathymetry/status.html.

Shields, F.D., Jr., Simon, Andrew, and Steffen, L.J., 2000, Reservoir effects on downstream river channel migration: Environmental Conservation, v. 27, no. 1, p. 54-66, accessed January 24, 2014, at http://journals.cambridge.org/ article_S0376892900000072.

Skinner, K.D., 2009, Evaluation of lidar-acquired bathymetric and topographic data accuracy in various hydrogeomorphic settings in the lower Boise River, southwestern Idaho, 2007: U.S. Geological Survey Scientific Investigations Report 2009-5260, 12 p. [Also available at http://pubs.usgs.gov/ sir/2009/5260/.]

Snyder, G.I., 2012, National Enhanced Elevation Assessment at a glance: U.S. Geological Survey Fact Sheet 2012-3088, 2 p., accessed September 15, 2015, at http://pubs.usgs.gov/ fs/2012/3088/. 
Stoker, J.M., Heidemann, H.K., Evans, G.A., and Greenlee, S.K., 2013, A conceptual prototype for the next-generation National Elevation Dataset: U.S. Geological Survey OpenFile Report 2013-1023, 52 p., accessed September 4, 2014, at http://pubs.usgs.gov/of/2013/1023/ofr13-1023.pdf.

U.S. Army Corps of Engineers, 1994, Channel stability assessment for flood control projects: Washington, D.C., U.S. Army Corps of Engineers, EM 1110-2-1418, accessed August 27, 2014, at http://www.publications.usace.army. mil/Portals/76/Publications/EngineerManuals/EM_1110-21418.pdf.

U.S. Army Corps of Engineers, 2002, Hydrographic surveying: Washington, D.C., U.S. Army Corps of Engineers, Draft EM 1110-2-1003, 506 p., accessed October 11, 2015, at http://www.publications.usace.army.mil/USACEPublications/EngineerManuals.aspx?udt_43544_param_page=4.

U.S. Army Corps of Engineers, 2013, Hydrographic surveying - Chapter 3: U.S. Army Corps of Engineers, EM 1110-2-1003, accessed September 16, 2015, at http://www. publications.usace.army.mil/Portals/76/Publications/EngineerManuals/EM_1110-2-1003.pdf.

U.S. Army Corps of Engineers, 2010, Mount St. Helens project, Cowlitz River levee systems - 2009 level of flood protection update summary: Portland, Oreg., U.S. Army Corps of Engineers, 271 p., accessed August 27, 2014, at http://cdm16021.contentdm.oclc.org/cdm/ref/collection/ p16021coll3/id/82.

U.S. Army Corps of Engineers, 2014a, Charts download: U.S. Army Corps of Engineers, Inland Electronic Navigational Charts, accessed August 11, 2014, at http://ec2-54-235-7627.compute-1.amazonaws.com/ienc/web/main/ienc_005. htm.

U.S. Army Corps of Engineers, 2014b, Hydrographic surveys: U.S. Army Corps of Engineers, Portland District, accessed September 23, 2014, at http://www.nwp.usace.army.mil/ Missions/Navigation/Surveys.aspx.

U.S. Army Corps of Engineers, 2014c, USACE inland electronic navigational charts (IENC): U.S. Army Corps of Engineers, MAPPS Breakfast at ASPRS, Louisville, Ky., March 26, 2014, accessed September 2, 2014, at http://c. ymcdn.com/sites/www.mapps.org/resource/resmgr/Federal_Issues_USACE/IENC-Mapps-2014.pdf.

U.S. Army Corps of Engineers, 2014d, IENC program overview: U.S. Army Corps of Engineers, Army Geospatial Center, accessed August 8, 2014, at http://www.agc.army. mil/Missions/Echarts.aspx.

U.S. Army Corps of Engineers, 2014e, HEC-RAS: U.S. Army Corps of Engineers, Hydrologic Engineering Center, accessed August 7, 2014, at http://www.hec.usace.army.mil/ software/hec-ras/features.aspx.
U.S. Bureau of Reclamation, Denver Office, Technical Service Center, 2006, Reservoir survey and data analysis, chap. 9 of Erosion and sedimentation manual: U.S. Department of the Interior, Bureau of Reclamation, p. 9-1-9-63. [Also available at http://www.worldcat.org/title/erosion-and-sedimentation-manual/oclc/122392286.]

U.S. Census Bureau, Population Division, 2005, 2005 interim state population projections by age and sex-2004-2030: U.S. Census Bureau, accessed September 16, 2015, at https://www.census.gov/population/projections/data/state/ projectionsagesex.html.

U.S. Environmental Protection Agency, 2014, Climate change indicators in the United States-Streamflow: U.S. Environmental Protection Agency, accessed January 26, 2015, at http://www.epa.gov/climatechange/science/indicators/ecosystems/streamflow.html.

U.S. Environmental Protection Agency, 2014, Water use today: U.S. Environmental Protection Agency, WaterSense, accessed June 30, 2015, at http://www.epa.gov/WaterSense/ our_water/water_use_today.html.

U.S. Environmental Protection Agency, 2014, (FY12) Suwannee River FL 1.0 meter lidar: Tampa, Fla., Digital Aerial Solutions, LLC, accessed January 14, 2015, at http://digitalaerial.com/suwannee-river-expansion-1-0-meter-lidar.

U.S. Geological survey, 2003, A tapestry of time and terrainThe union of two maps, geology and topography: U.S. Geological Survey, accessed September 15, 2015, at http:// tapestry.usgs.gov/two/two.html.

U.S. Geological Survey, 2011, Bathymetric data for the upper Mississippi River system: U.S. Geological Survey, Upper Midwest Environmental Sciences Center, The Long Term Resource Monitoring Program, accessed June 24, 2015, at http://www.umesc.usgs.gov/aquatic/bathymetry.html.

U.S. Geological Survey, 2014a, 3D Elevation Program (3DEP): U.S. Geological Survey, The National Map, accessed September 2, 2014, at http://nationalmap. gov/3DEP/.

U.S. Geological Survey, 2014b, Spatial data transfer standard (SDTS): U.S. Geological Survey Fact Sheet 205-95, accessed September 15, 2015, at http://pubs.er.usgs.gov/ publication/fs20595.

Vermeyen, Tracy, and Wahl, Tony, 1999, Experiences using acoustic Doppler current profilers (ADCP) for physical model calibrations: International Symposium on Ecohydraulics, 3d, Salt Lake City, Utah, July 13-19, 1999 [Proceedings], accessed June 25, 2015, at http://www.usbr.gov/ tsc/techreferences/hydraulics_lab/pubs/PAP/PAP-0961.pdf. 
Wang, Dingbao, and Hejazi, Mohammad, 2011, Quantifying the relative contribution of the climate and direct human impacts on mean annual streamflow in the contiguous United States: Water Resources Research, v. 47, no. 10, 16 p. [Also available at http://dx.doi. org/10.1029/2010WR010283.]

Warren, Joseph, 2010, Basics of acoustic scattering: New York, Stonybrook University, Marine Sciences Research Center, accessed June 25, 2015, at http://www.somas.stonybrook.edu/ warren/seabass/seabass_active_acoustics_lecture_1_web.pdf.

Wright, C.W., and Brock, J.C., 2014, USGS coastal 3DEPCoastal National Elevation Database (CoNED) status report: U.S. Geological Survey, Coastal and Marine Geology Program, accessed September 29, 2014, at http://shoals. sam.usace.army.mil/Workshop_Files/2014/Day1_pdf/1000_ Brock.pdf. 

Appendixes 1-3 


\section{Appendix 1. National Geospatial Program Light Detection and Ranging Base Specification Requirements for Hydroflattening and Breaklines}

1. Inland ponds and lakes:

- Water bodies of 8,000 square meters $\left(\mathrm{m}^{2}\right)$ (2 acres) or greater surface area at the time of collection shall be flattened.

- Flattened water bodies shall present a flat and level water surface (a single elevation for every bank vertex defining the perimeter of the waterbody).

- The water-surface edge shall be at or below the immediately surrounding terrain (the presence of floating water bodies will be cause for rejection of the deliverable).

- Long impoundments-such as reservoirs, inlets, and fjords whose water-surface elevations decrease with downstream travel— shall be treated as streams or rivers.

2. Inland streams and rivers:

- Streams and rivers of a nominal, 30-meter (m) width shall be flattened.

- Streams or rivers whose width varies greater than and less than $30 \mathrm{~m}$ will not be broken into multiple segments; data producers will use their best professional cartographic judgment in determining when a stream or river has attained a nominal, 30-m width.

- Flattened streams and rivers shall present a flat and level water surface bank-to-bank (perpendicular to the apparent flow centerline).

- Flattened streams and rivers shall present a gradient downhill water surface following the immediately surrounding terrain.

- In cases of sharp turns of rapidly moving water, where the natural water surface is notably not level bank-tobank, the water surface will be represented as it exists while maintaining an aesthetic cartographic appearance.

- The entire water-surface edge shall be at or below the immediately surrounding terrain.

- Stream channels shall break at culvert locations leaving the roadway over the culvert intact.

- Bridges in all their forms shall be removed from the digital elevation model (DEM).

- Streams shall be continuous at bridge locations.
- When the identification of a structure as a bridge or culvert cannot be made definitively, the feature shall be regarded as a culvert.

3. Nontidal boundary waters:

- Boundary waters, regardless of size, shall be represented only as an edge or edges within the project; collection does not include the opposite shore.

- The entire water-surface edge shall be at or below the immediately surrounding terrain.

- The water-surface elevation will be consistent throughout the project.

- The water surface shall be flat and level, as appropriate for the type of waterbody (level for lakes, a gradient for streams and rivers).

- Any unusual changes in the water-surface elevation during the course of the collection (such as increased upstream dam discharge) shall be documented in the project metadata.

- In the event of an unusual change in water-surface elevation, the waterbody shall be handled as described below.

4. Tidal waters:

Tidal water bodies are any waterbody that is affected by tidal variations, including oceans, seas, gulfs, bays, inlets, salt marshes, and large lakes. Tidal variations during data collection or between data collections will result in lateral and vertical discontinuities along shorelines. To align with the intent of the U.S. Geological Survey (USGS) National Geospatial Program (NGP) for the DEM to represent as much ground as the collected data permit, lidar ground points shall not be removed for the sake of adjusting a shoreline inland to match another shoreline. Likewise, adjusting a shoreline outland will create an equally unacceptable area of unmeasured land in the DEM. It is recommended that, to the highest degree practical, collections be planned to minimize tidal differences at the land-water interface. In addition to meeting the requirements for inland water bodies listed above, as appropriate, the treatment of tidal water bodies shall also meet the following requirements:

- Within each waterbody, the water surface shall be flat and level for each different water-surface elevation.

- Vertical discontinuities within a waterbody resulting from tidal variations during the collection are considered normal and shall be retained in the final DEM. 
- Horizontal discontinuities along the shoreline of a waterbody resulting from tidal variations during the collection are considered normal and shall be retained in the final DEM.

- Long, tidal water bodies that also exhibit downhill flow (such as a fjord) can present unusual challenges; data producers are to exercise their best professional judgment in determining the appropriate approach solution to meet the overall goal of hydroflattening as described in this section. For projects in coastal areas, cooperating partners may impose additional requirements for tidal coordination.

5. Islands:

- Permanent islands $4,000 \mathrm{~m}^{2}$ ( 1 acre) or greater shall be delineated within all water bodies.

Please refer to Heidemann (2014) for more information.

\section{Reference Cited}

Heidemann, H.K., 2014, Lidar base specification (v. 1.2, November 2014): U.S. Geological Survey Techniques and Methods, book 11, chap. B4, 67 p. with appendixes. [Also available at http://dx.doi.org/10.3133/tm11B4.] 


\section{Appendix 2. Inland Bathymetry Surveys for Rivers and Lakes}

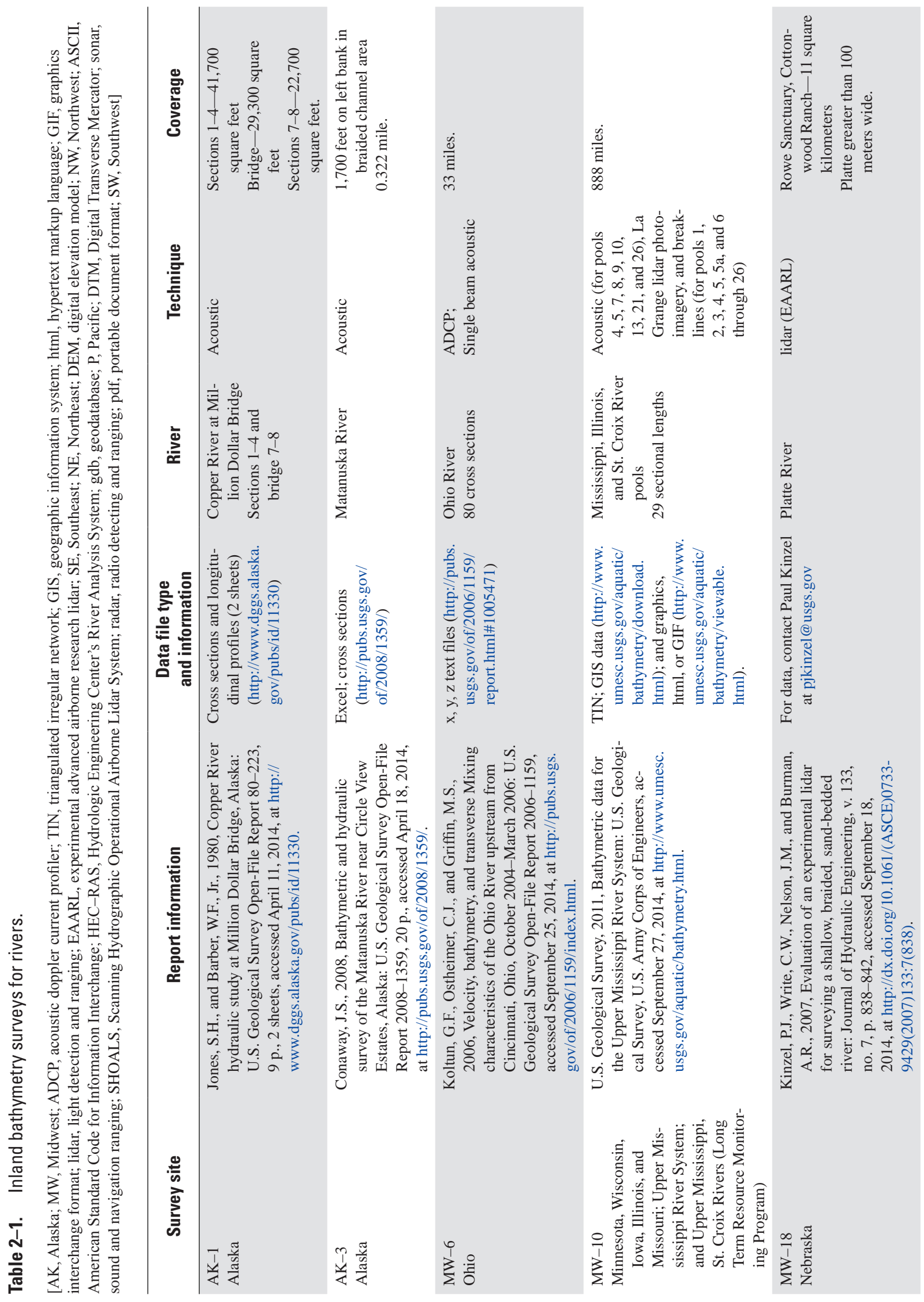




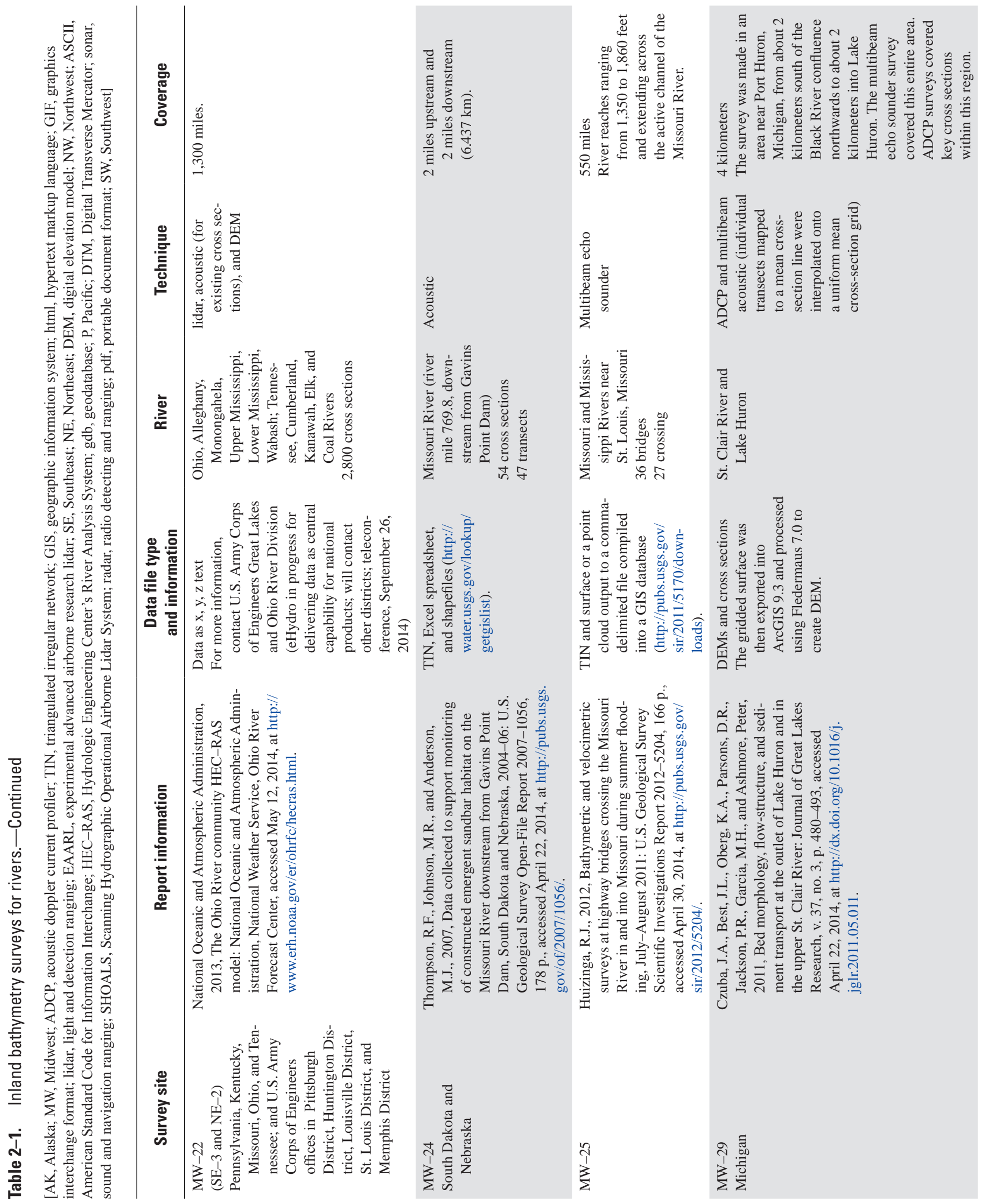




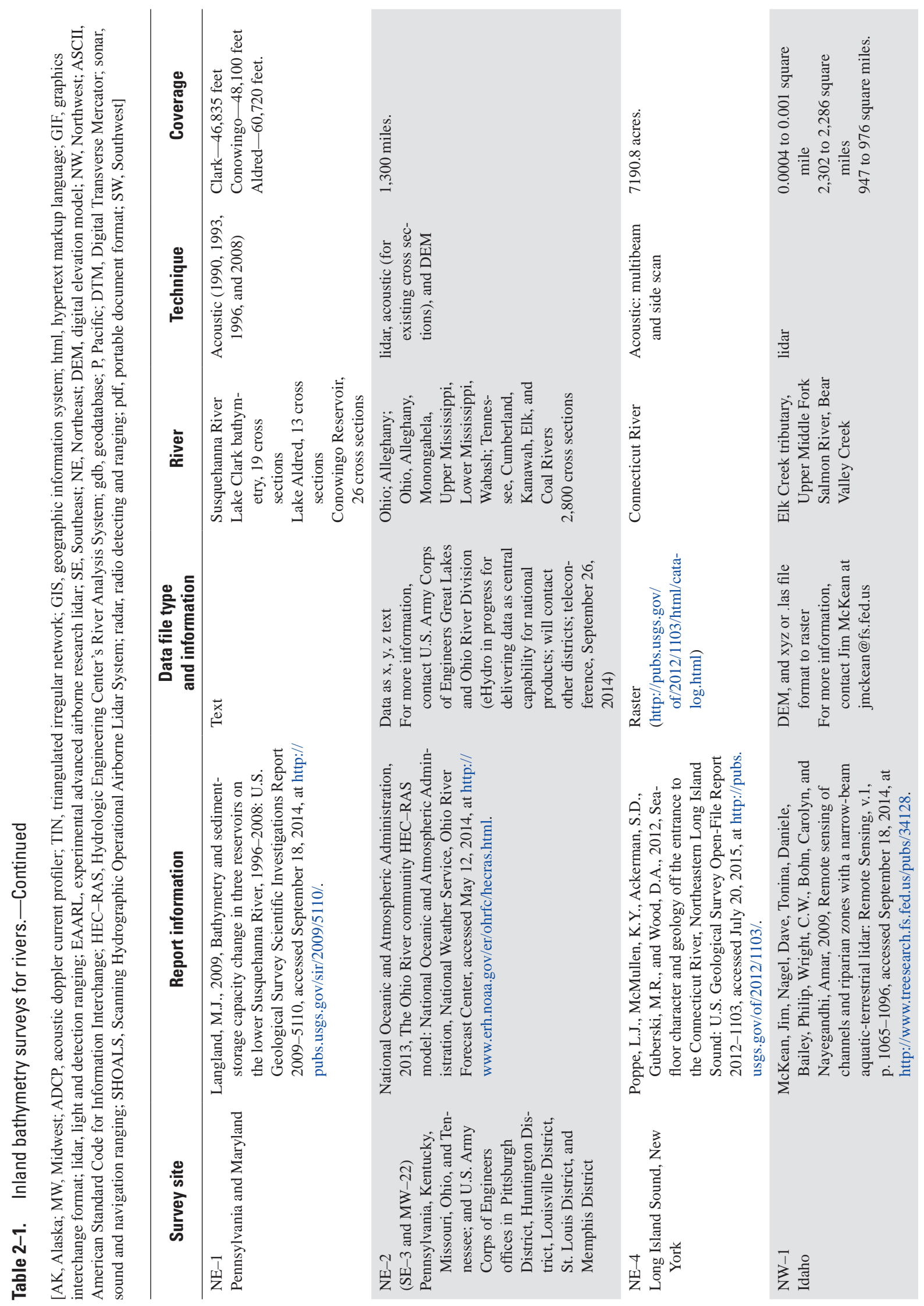




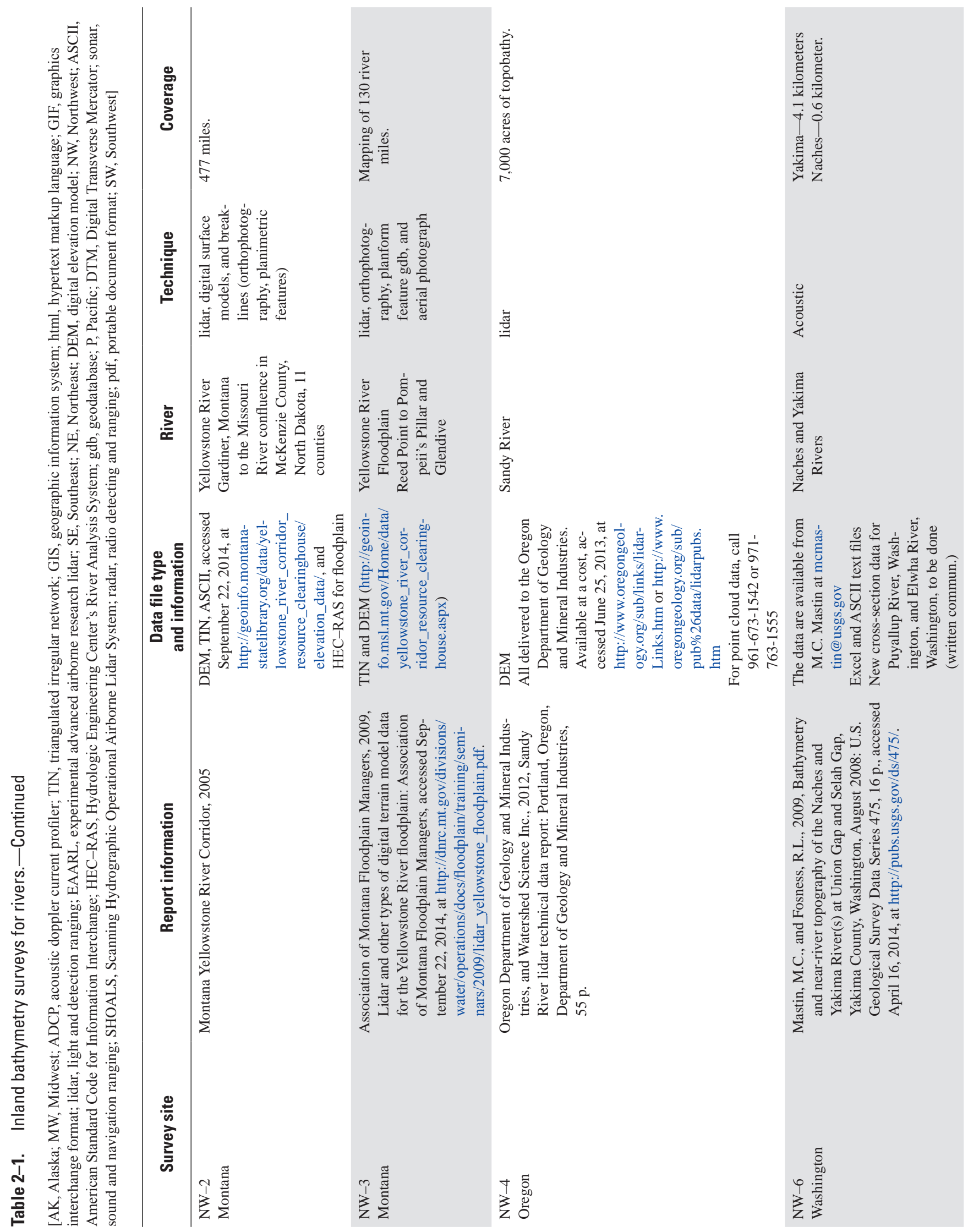




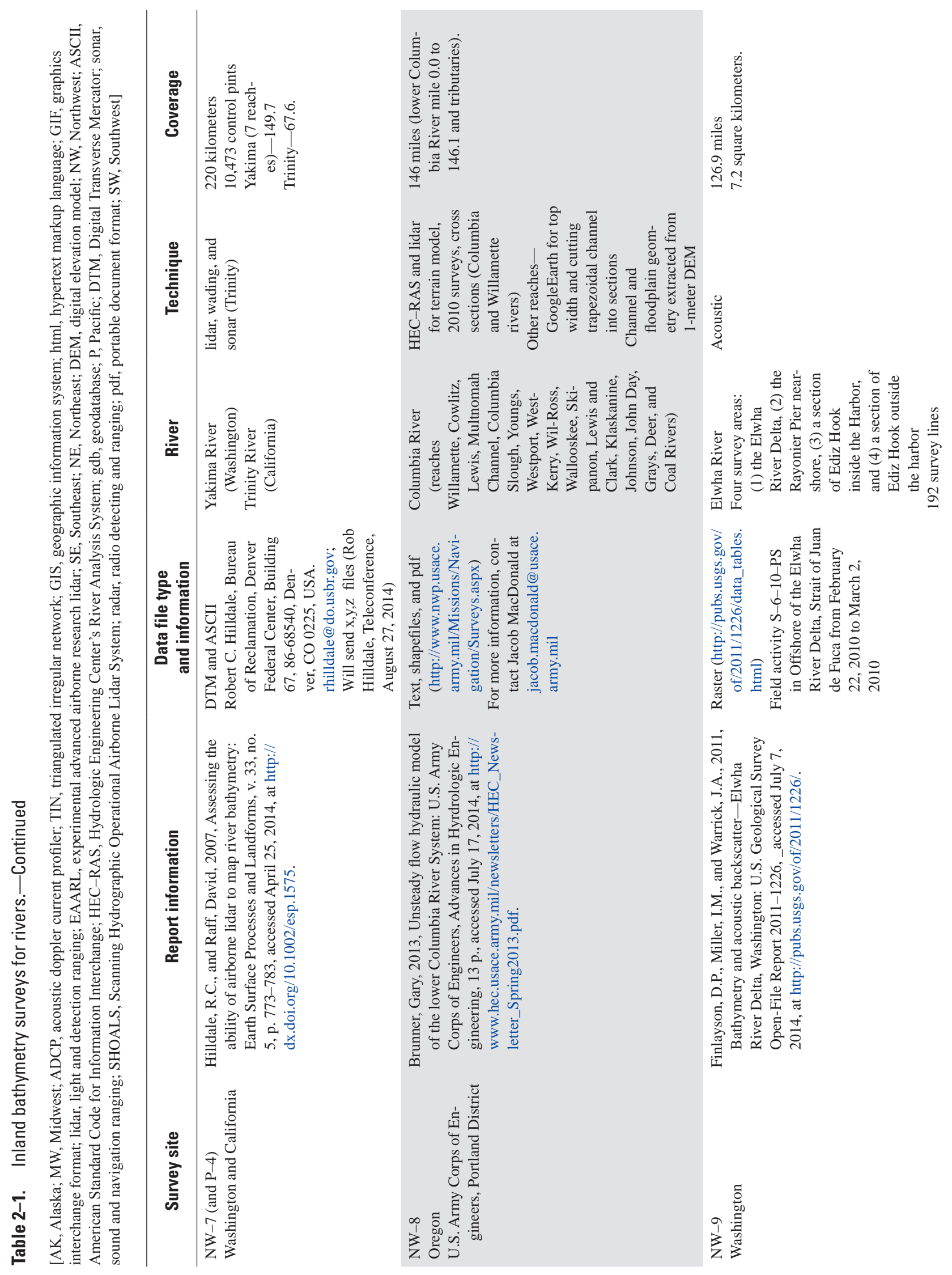




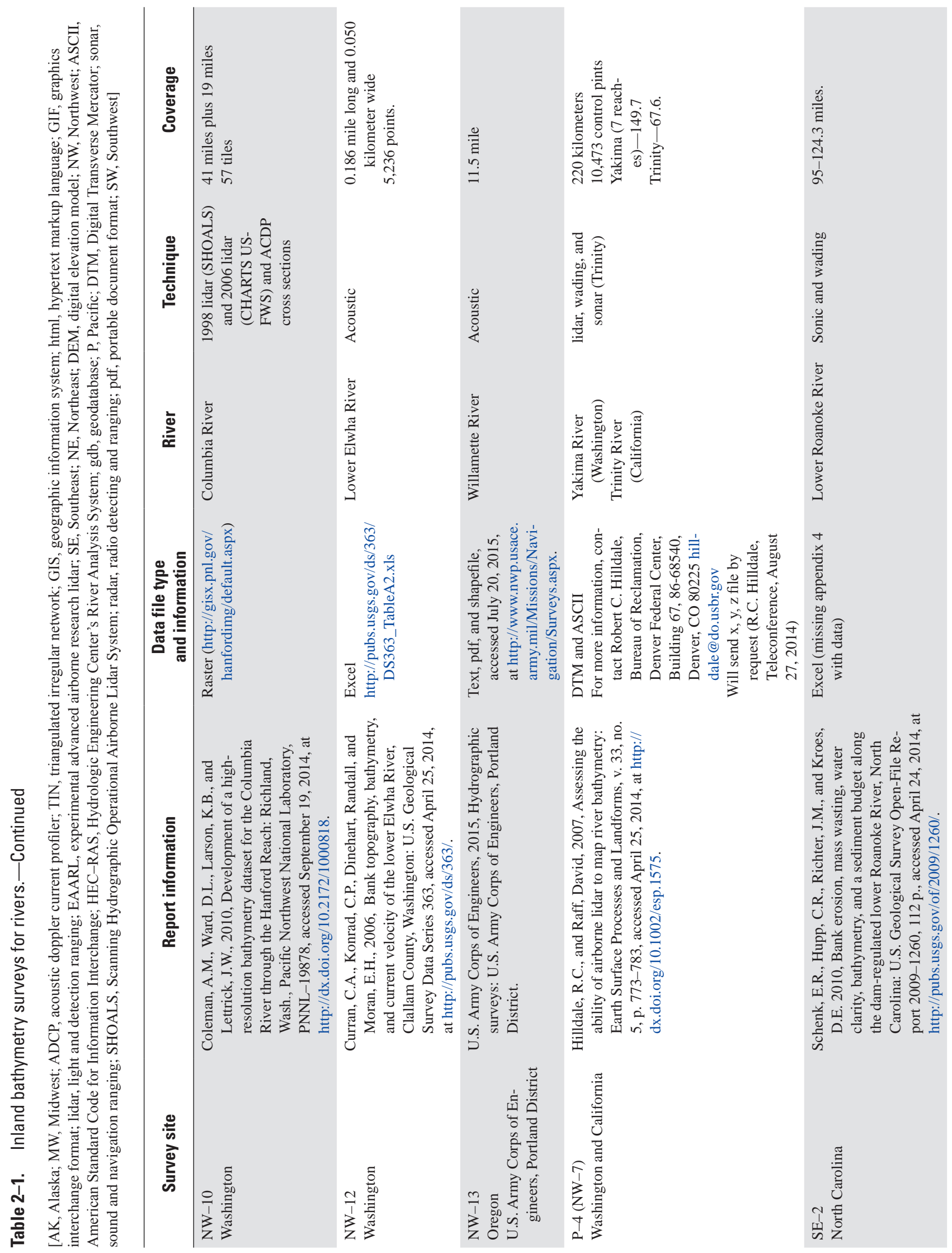




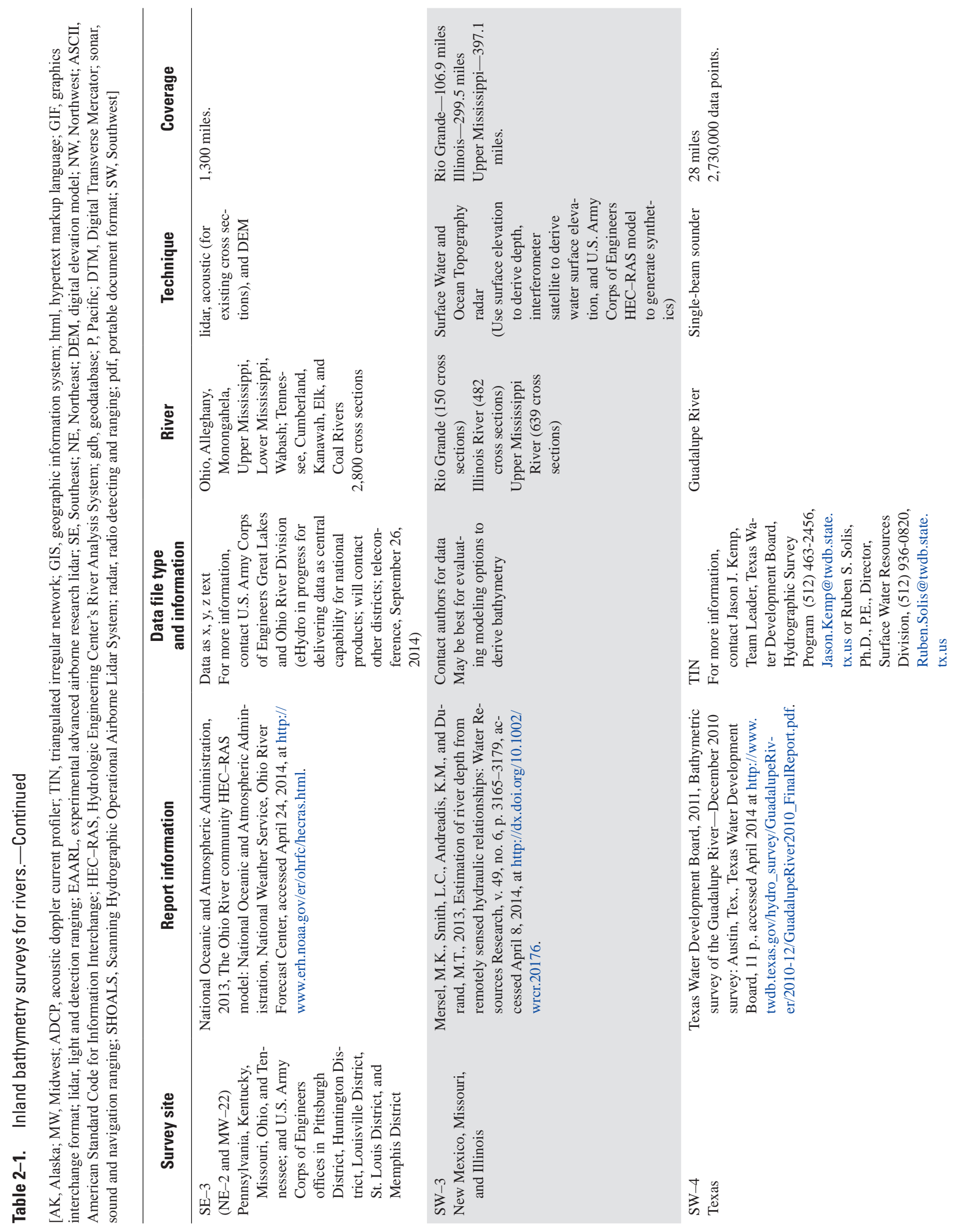




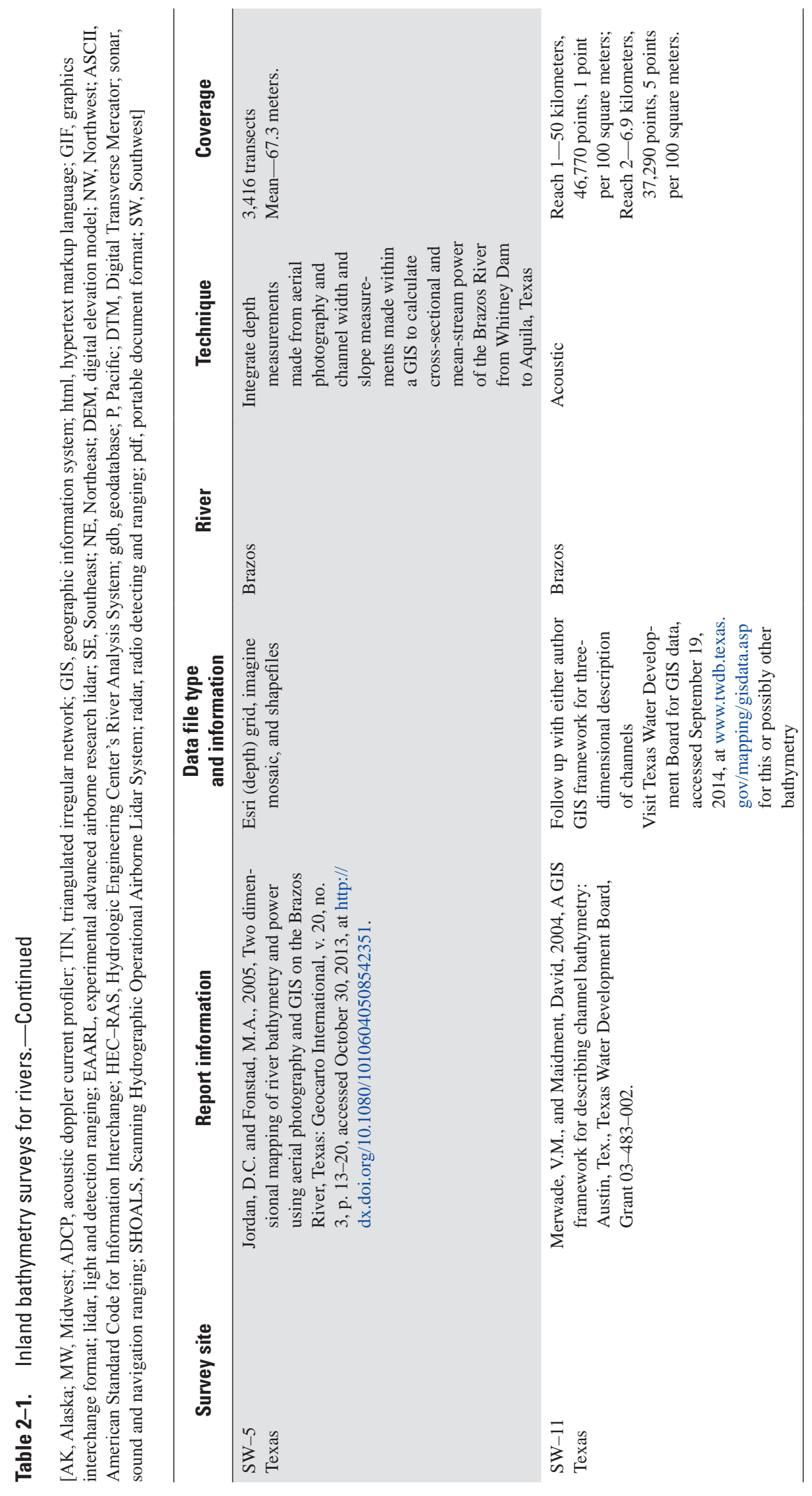




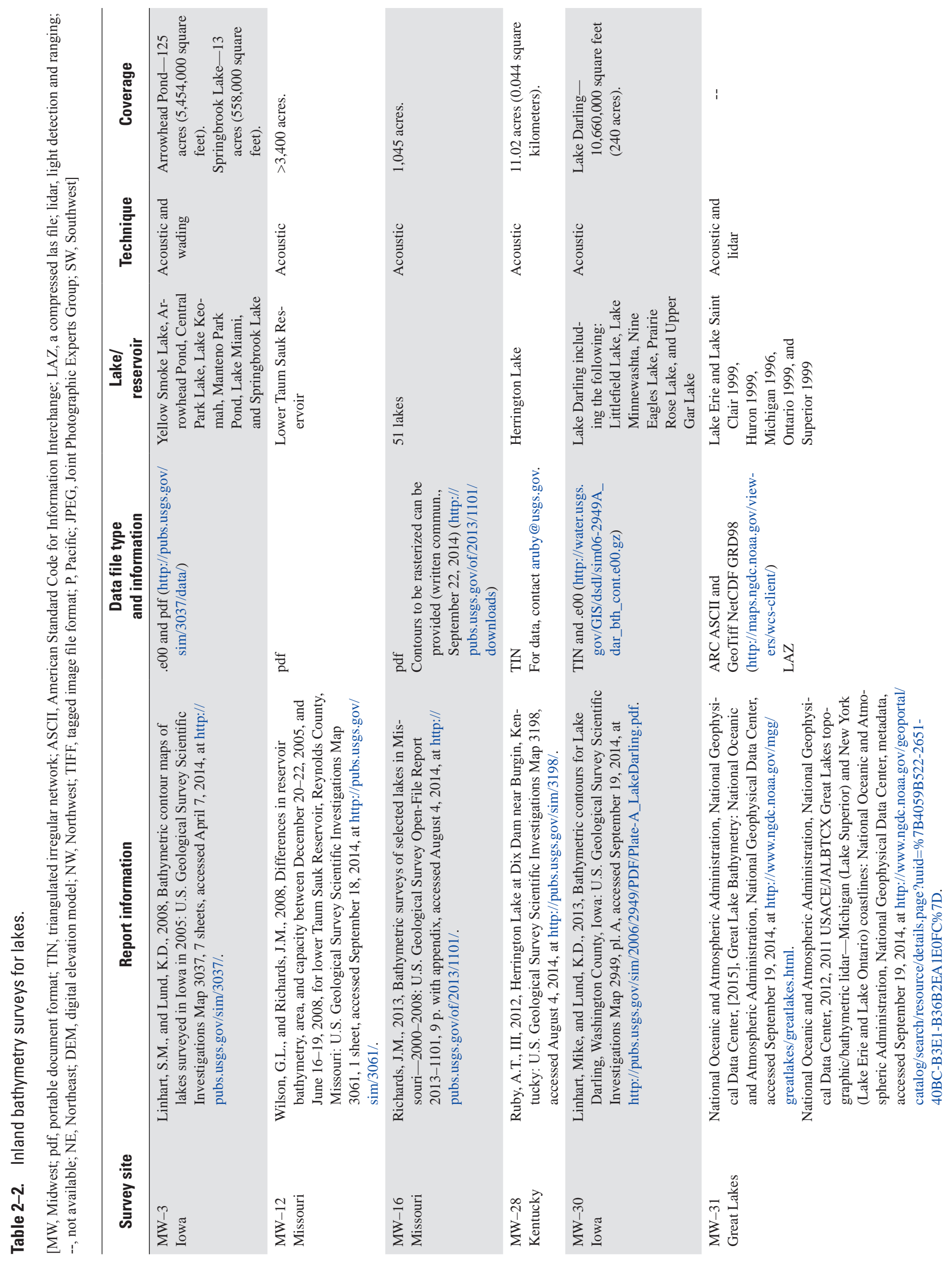




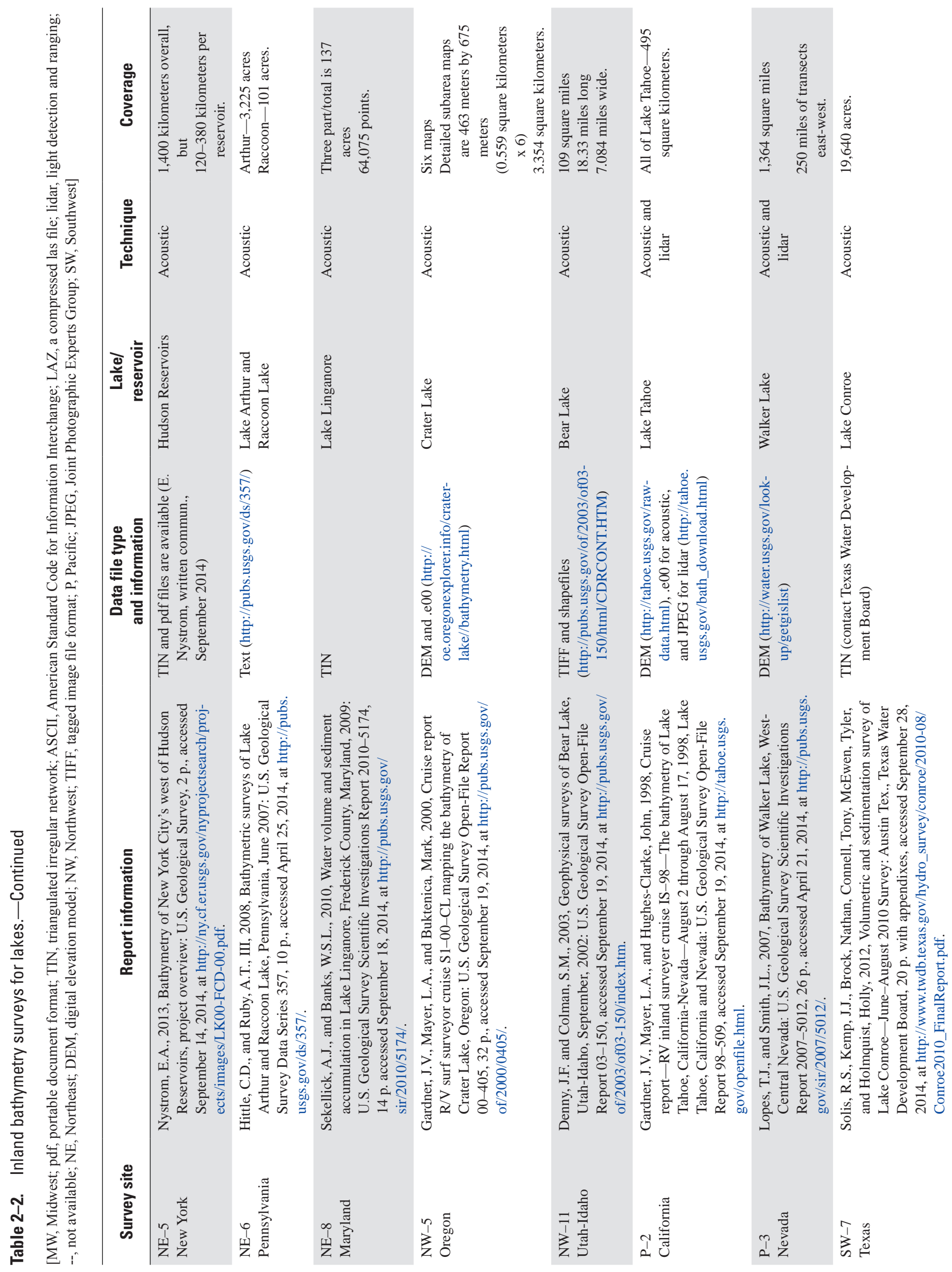




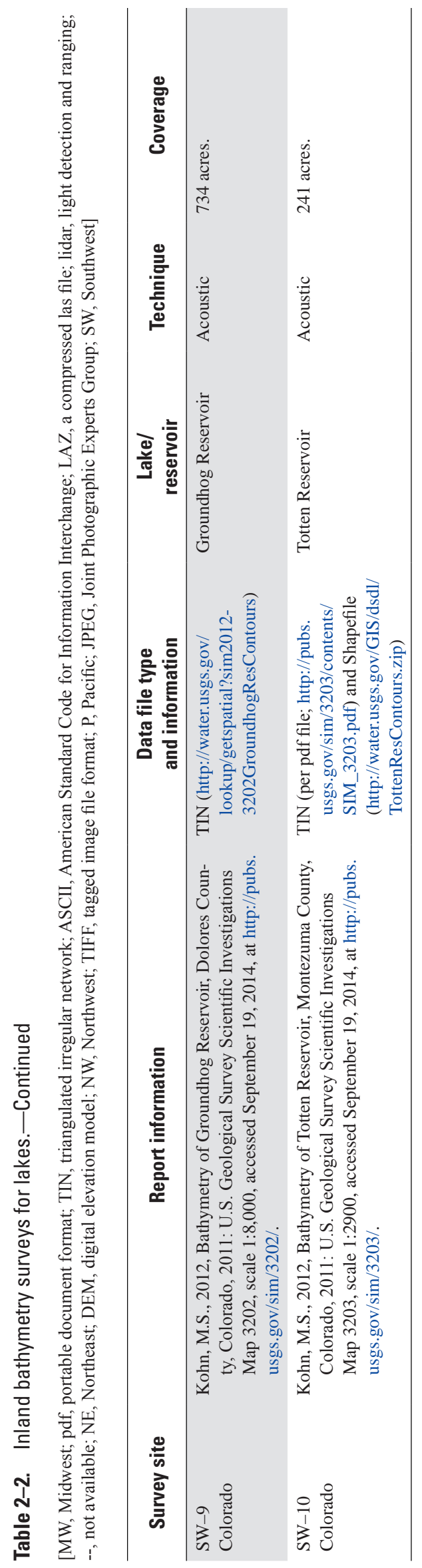




\section{Appendix 3. National Oceanic and Atmospheric Administration Bathymetry}

\section{Resources}

The National Oceanic and Atmospheric Administration (NOAA) produces bathymetric and topobathymetric maps as digital elevation models (DEMs) for various purposes. These are briefly described as a quick reference to available resources that could be integrated or that could provide background for developing bathymetric surveys in common areas.

\section{Estuarine Bathymetry-Gridded Digital Sounding Data}

The NOAA Special Projects Office provides digital, gridded, sounded data products for estuarine bathymetry for those estuaries that contain more than 80 percent spatial coverage of digital sounding data (70 or more of the 130 or more estuaries). These datasets can be retrieved from the NOAA National Ocean Service (NOS) Data Explorer service (National Oceanic and Atmospheric Administration, National Ocean Service, 2014a). Each archive file contains the products applicable to one of two datasets: a DEM for 30-meter (m) gridded bathymetry, and a DEM for 90-m (3 arc-second) gridded bathymetry. The 3 arc-second bathymetric data were derived from the higher resolution (30 m) gridded bathymetry. Bathymetric elevations within these datasets are referenced to the local tidal datum, which typically is Mean Lowest Low Water (MLLW) averaged over a 19-year tidal epoch. Each dataset is supported by visual images and text files. All nautical charts produced by the NOAA, Office of Coastal Survey are available in a raster format as geo-referenced, digital image Raster Navigational Charts (RNCs) that conform to the BSB file format specification (International Hydrography Organization, 2004). Although in a raster format, RNC metadata reveal scales for a project may be variable, and all map scales are commonly smaller than 3 arc-seconds $(1: 250,000)$ so that, as rendered, these raster data are not suited for integration.

\section{Digital Elevation Models}

The NOAA National Geophysical Data Center (NGDC) builds and distributes high-resolution, coastal DEMs that integrate ocean bathymetry and land topography to develop topobathymetry products that display as integrated models of coastal relief (National Oceanic and Atmospheric Administration, National Geophysical Data Center, 2014c). The topographic data are typically from the U.S Geological Survey (USGS) 3D Elevation Program (3DEP), the National Aeronautics and Space Administration Space Shuttle Topography Mission, and high-resolution (1- to 10-meter point spacing) redlaser light detection and ranging (lidar) surveys. Bathymetric, topographic, and shoreline data used in DEM compilation are obtained from various sources, including the NOAA NGDC, the U.S. Coastal Services Center (CSC), the U.S. Office of Coast Survey (OCS), and the U.S. Army Corps of Engineers (USACE), as well as other Federal, state, and local government agencies, academic institutions, and private companies. The DEMs are referenced to the vertical tidal datum of North American Vertical Datum of 1988 (NAVD 88) or Mean High Water (MHW) and the horizontal datum of North American Datum of 1983 (NAD 83).

The DEM catalogs are available for Alaska, the Caribbean, the East Coast, the Gulf of Mexico coast, the Pacific Islands, and the West Coast (National Oceanic and Atmospheric Administration, National Geophysical Data Center, 2014d). Coverage provided by these DEMs is commonly for ports or large bays. Although these are coastal mapping projects, these surveys can provide bathymetry for communities and primary rivers emptying into coastal zones, such as the Astoria, Oregon, DEM that encompasses the mouth of the Columbia River or the LaPush, Washington, DEM that provides coverage of the entire coastal region at the mouth of the Quillayute River (fig. 3-1).

The DEM projects can include multiple DEMS, both 7.5-minute DEMS and one-degree DEMs formatted as ASCII files in the file format adopted by the USGS and the National Imagery and Mapping Agency (National Oceanic and Atmospheric Administration, National Geophysical Data Center, 2014d). The datum for these bathymetric DEMs is not the same as that used by the USGS for land-based DEMs, which results in a discontinuity if the two datasets are merged together. In some regions the only source data were at fathom (6 feet) resolution. (Most source surveys were certified to 1 foot or less by the NOAA NOS.) The horizontal accuracy of a DEM is an estimated root mean square error (RMSE) based on horizontal accuracy tests of the source soundings used to generate the DEM. Estimated accuracy of bathymetric DEMs is 2 percent of depth or $1 \mathrm{~m}$ for depths more than $20 \mathrm{~m}$ and 2 percent of depth or $0.20 \mathrm{~m}$ for depths less than $20 \mathrm{~m}$.

\section{Vertical Datum Transformation Maps}

The NOAA provides coastal topobathymetry DEMs integrated using the vertical datum transformation (VDatum) tool (National Oceanic and Atmospheric Administration, National Geophysical Data Center, 2014b). Specific to the Gulf of Mexico, the NOAA NGDC has developed DEMs for New Orleans, Louisiana; Mobile, Alabama; and Panama City, Florida. These maps are created to show continuous elevations through the transition from topography to bathymetry and may also provide a useful resource. The DEMs for this project include coverage extending into Lake Pontchartrain, Louisiana; Mobile Bay, Alabama; and Panama City, Florida, on St. Andrews Bay, a 69,000-acre estuary (fig. 3-2). These resources may provide useful inland bathymetry data and at a minimal cost. These 


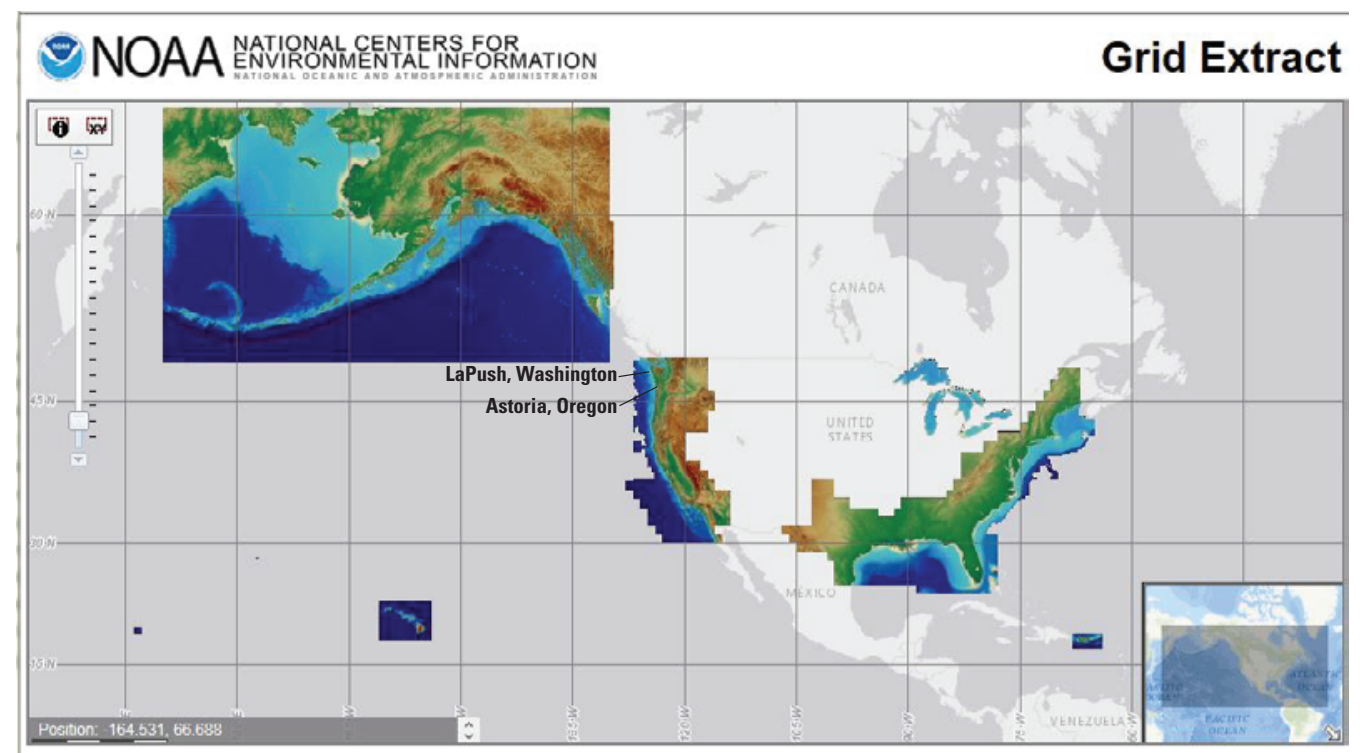

\begin{tabular}{|c|c|c|c|c|}
\hline 1. Choose a Layer & \multirow{3}{*}{ 2. Select an Area from the map } & \multicolumn{2}{|c|}{ 3. Choose Output Format } & \multirow[t]{3}{*}{ 4. Dovmload the Data } \\
\hline Coastal Relief Models & & & & \\
\hline $\begin{array}{l}\text { Coastal Relief Model (3-second } \\
\text { resolution) }\end{array}$ & & GeoTIFF &. & \\
\hline
\end{tabular}

Figure 3-1. Northwest Pacific Coastal Relief Model.

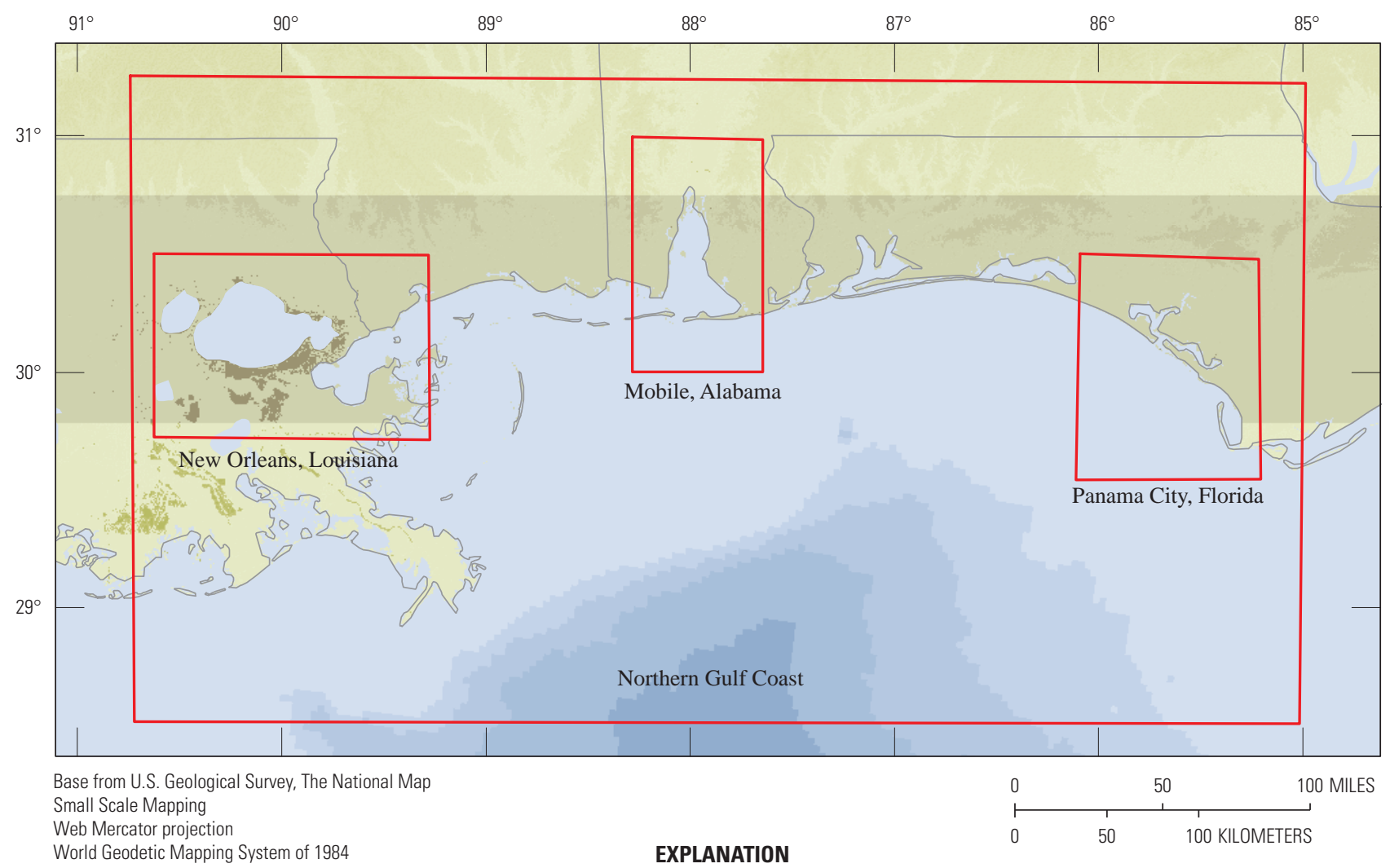

World Geodetic Mapping System of 1984

National Oceanic and Atmospheric Administration vertical datum for the Gulf of Mexico

Figure 3-2. National Oceanic and Atmospheric Administration vertical datum transformation tool for the Gulf of Mexico. 
data have been used in the USGS 3DEP CoNED Program to provide seamless bathymetry to topographic transitional zone DEMs for the northern Gulf of Mexico and Delaware Bay, and the VDatum tool may prove useful for future USGS projects.

\section{Inland Electronic Navigation Charts for Rivers}

The NOAA Inland Electronic Navigation Chart (IENC) program provides vector format bathymetry data as ASCII text files (U.S. Army Corps of Engineers, 2014a). A snapshot from the USACE IENC program shows surveys extending up the Mississippi River and inland along primary river channels, tributaries, and embayments such as the Columbia River, San Francisco Bay, Chesapeake Bay, the Hudson River, and the Great Lakes (fig. 3-3).

Within the United States, about 107 IENCs are available for surveys along rivers (table 3-1) where different surveys may have been completed for sections of each river (reach). Hydrographic survey data are available through the USACE district office for the area of interest, as ASCII text datasets at various scales ranging from 1:2,500 to 1:10,000. Charts may be downloaded as Google Earth KML, IHO S-57 cells, or Esri shapefiles (U.S. Army Corps of Engineers, 2014b).

\section{Coastal Maintained Channels}

There are more than 9,000 maintained channels in the USACE inventory that includes coastal waterways and, important to inland topobathymetry resources, rivers that reach from the coast up into the mainland available through the NOAA. Surveys provide channel and channel limit (land/water interface) depths. Along with each reach name, the project dimensions are listed to include the width, project depth and length of the reach. For each reach, controlling depths are listed for the separate quarters of that reach and the date of the survey from which those controlling depths were taken. The controlling depths determined by the USACE are the shallowest depths for that quarter of the reach. Data are available as ArcGIS geodatabase files providing channel polygons (fig. 3-4). The USACE hydrographic surveys are typically completed at 1:2,500 with high-resolution detail. Metadata for the NOAA hydrographic survey for North Atlantic maintained channels indicates the maximum scale for intended use is 1:80,000 (National Oceanic and Atmospheric Administration, Office of Coastal Survey, 2013)

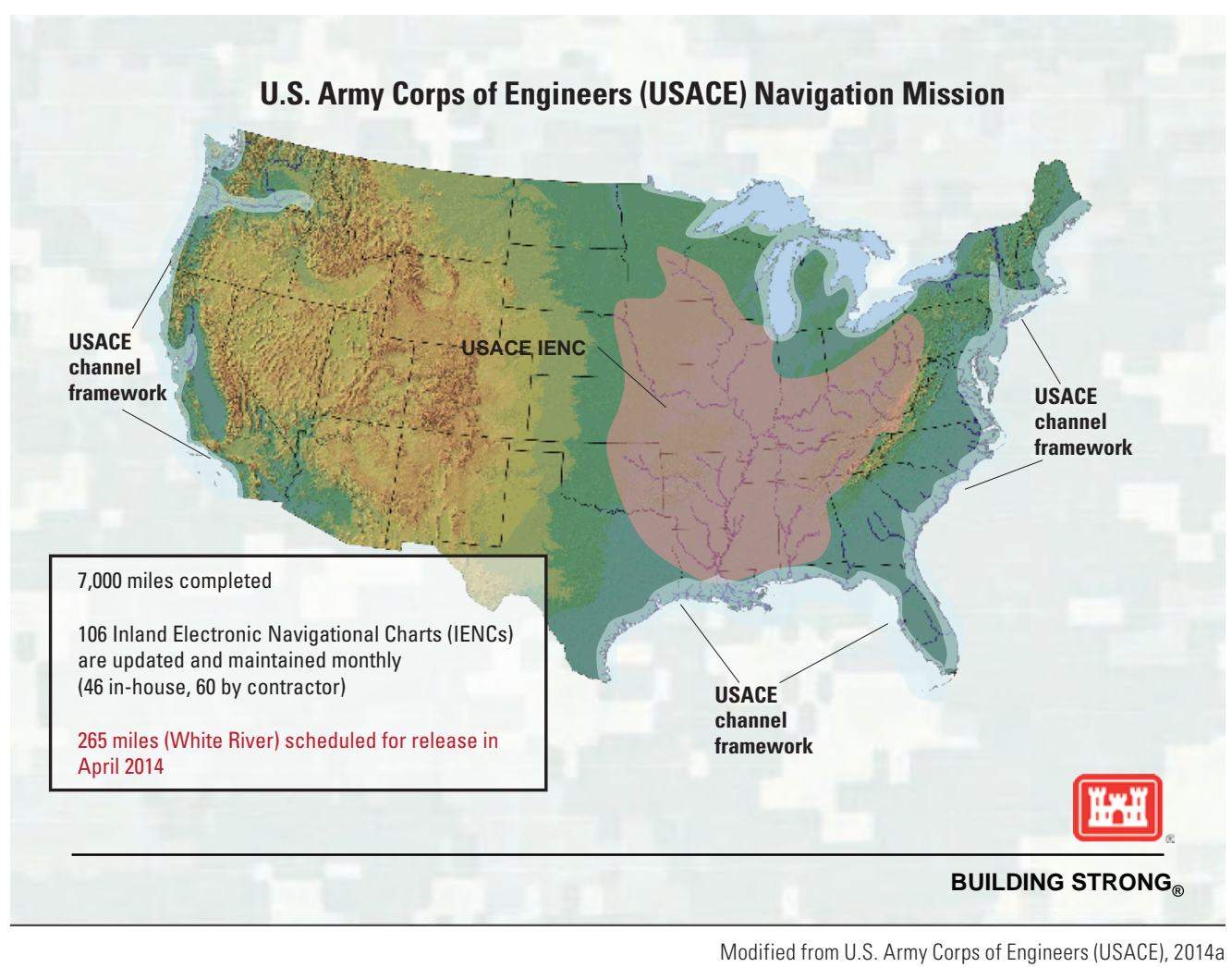

Figure 3-3. Inland Electronic Navigation Chart. 
42 Evaluating Integration of Inland Bathymetry in the U.S. Geological Survey 3D Elevation Program, 2014

Table 3-1. U.S. Army Corps of Engineers Inland Electronic Navigation Charts-River Surveys.

[--, no value]

\begin{tabular}{|lcc|}
\hline \multicolumn{1}{c}{ River } & $\begin{array}{c}\text { River } \\
\text { mile }\end{array}$ & $\begin{array}{c}\text { River } \\
\text { length } \\
\text { (kilometer) }\end{array}$ \\
\hline Allegheny River & $0-30$ & 48 \\
\hline Arkansas River & $0-444$ & 716 \\
\hline Atchafalaya River & $0-118$ & 190 \\
\hline Black Warrior-Tombigbee Rivers & $0-393$ & 632 \\
\hline Cumberland River & $0-381$ & 613 \\
\hline Green River & $1-108$ & 174 \\
\hline Illinois River & $0-322$ & 542 \\
\hline Kaskaskia & $2-36$ & 58 \\
\hline Kanawha River & $0-91$ & 146 \\
\hline Lower Mississippi River & $236-951$ & 1,151 \\
\hline Missouri River & $0-735$ & 1,180 \\
\hline Monongahela River & $0-128$ & 208 \\
\hline Ohio River & $0-981$ & 1,579 \\
\hline Ouachita River & $5-338$ & 565 \\
\hline Red River & $0-237$ & 381 \\
\hline Tennessee River (including Tellico, Hi- & $0-652$ & 1,231 \\
\hline wassee, Clinch, and Emory Rivers) & & \\
\hline Tennessee-Tombigbee Waterway & $218-450$ & 373 \\
\hline Upper Mississippi River & $0-866$ & 1,394 \\
\hline White River & -- & 394 \\
\hline
\end{tabular}



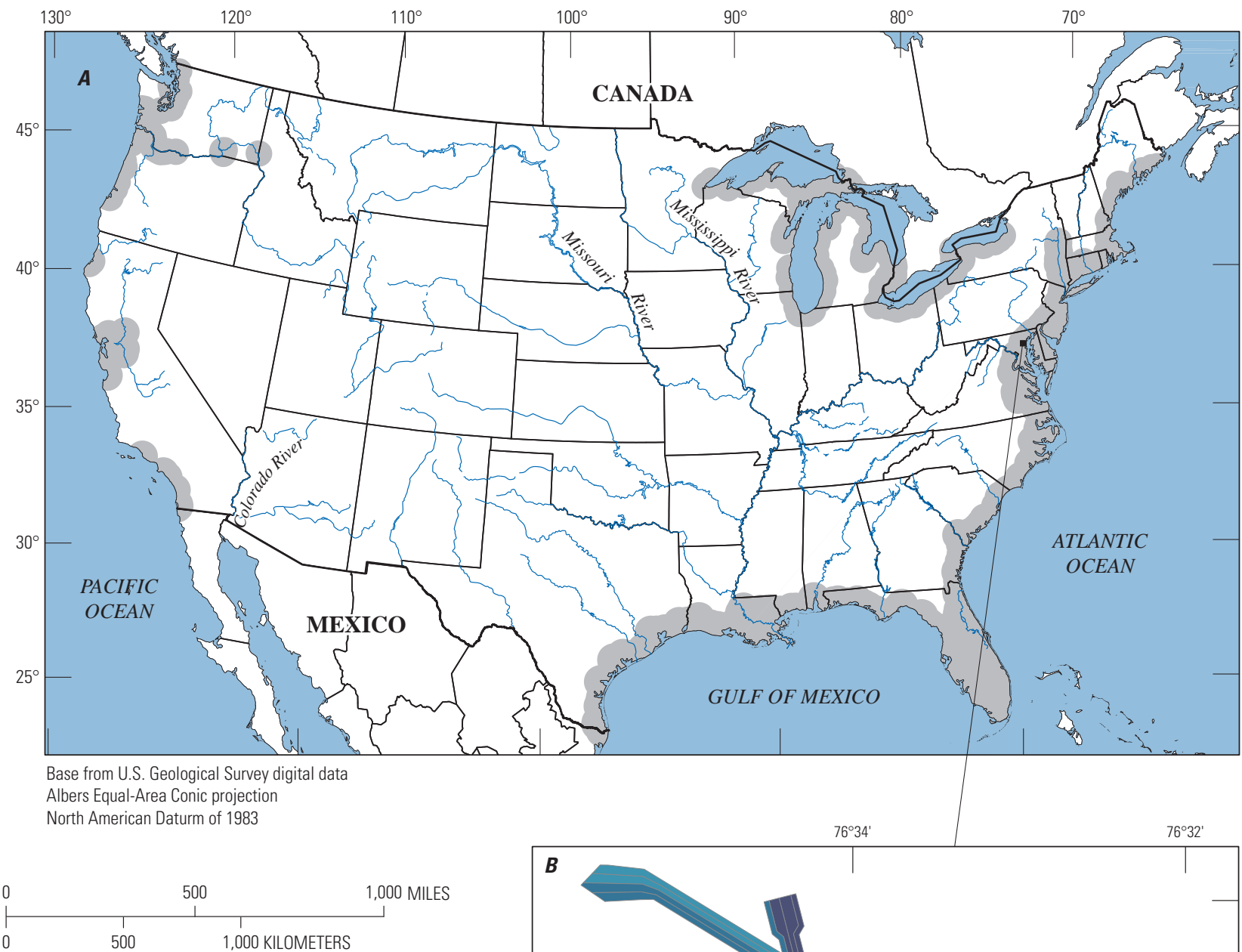

EXPLANATION

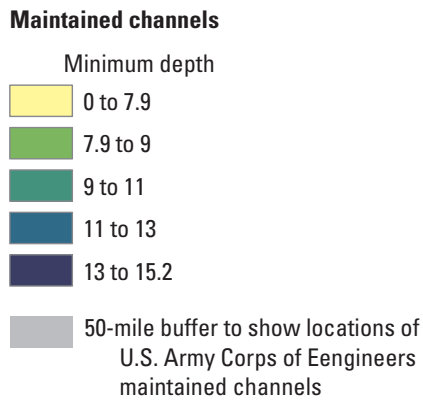

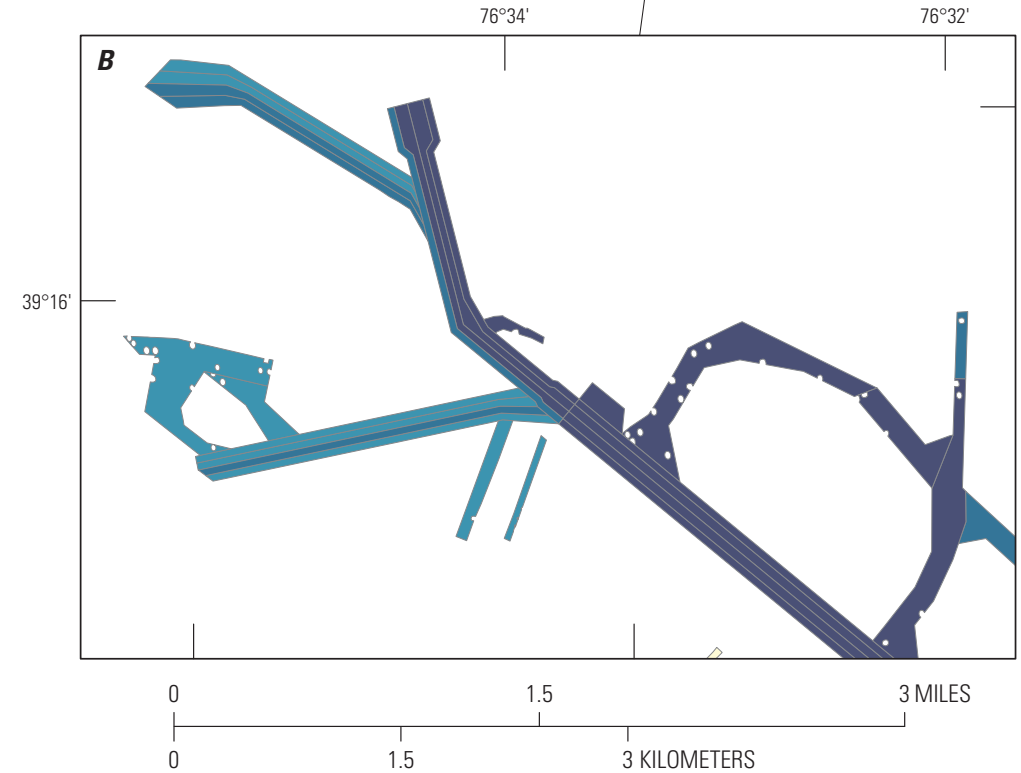

Figure 3-4. U.S. Army Corps of Engineers maintained channels. $A$, areas including maintained channel data. $B$, example for maintained channel minimum depth mapping. 


\section{National Oceanic and Atmospheric Administration Digital Coast-Light Detection and Ranging Bathymetry Surveys, 1999 to 2013}

Surveys to collect bathymetry, topobathymetry, and coastal topography and listed available through the NOAA Digital Coast Web site were completed by the USGS or USACE and are provided in the National Ocean Atmospheric Administration, Coastal Services Center (2014a). Nearly 80 lidar surveys are indexed for programs flown by either the USACE Joint Airborne Lidar Bathymetry Technical Center of Expertise or the USGS Joint Airborne Lidar Bathymetry Technical Center of Expertise flight-based systems. Data are available as points in ASCII $\mathrm{x}, \mathrm{y}, \mathrm{z}$, LAS, or LAZ; DEMs in floating point grid, GeoTIFF, and ASCII Grid; and contours in shapefile and AutoCad exchange formats. Point density is 0.1 to 8 points per square meter. Accuracy for elevations at 95-percent confidence is typically better than 30 centimeters.

Data downloads are available through the NOAA Digital Coast Data Web site hosting the File Transfer Protocol server at the Coastal Services Center in Charleston, South Carolina. Data are in geographic coordinates using the NAD 83. The version of the NAD 83 may vary slightly, but all are one of the updated realizations such as the High Accuracy Reference Network (HARN), Continuously Operating Reference System of 1996 (CORS 96), or National Spatial Reference System of 2007 (NSRS 2007), and not the original NAD 83. This may not be evident in the metadata. Vertical units are meters and all have been converted from NAD 83 ellipsoid heights to orthometric NAVD 88 heights using GEOID12a.

\section{References Cited}

International Hydrography Organization, 2004, BSB-Test data set: accessed October 12, 2014, at http://www.iho.int/ iho_pubs/standard/S-64/RNC_Test_Data_Sets/BSB_TDS/ BSB_TDS.htm.

National Oceanic and Atmospheric Administration, Coastal Services Center, 2014a, Digital coast: National Oceanic and Atmospheric Administration, Office for Coastal Management, Digital Coast Web site, accessed June 10, 2016, at http://estuarinebathymetry.noaa.gov/finddata.html.

National Oceanic and Atmospheric Administration, National Geophysical Data Center, 2014b, NOAA VDatum digital elevation model (DEM) project: National Oceanic and Atmospheric Administration, National Geophysical Data Center, accessed June 24, 2015, at http://www.ngdc.noaa. gov/mgg/inundation/vdatum/vdatum.html.
National Oceanic and Atmospheric Administration, National Geophysical Data Center, 2014c, Integrated models of coastal relief: National Oceanic and Atmospheric Administration, National Geophysical Data Center, accessed October 4, 2014, at http://www.ngdc.noaa.gov/mgg/coastal/.

National Oceanic and Atmospheric Administration, National Geophysical Data Center, 2014d, Digital elevation model (DEM) discovery portal: National Oceanic and Atmospheric Administration, National Geophysical Data Center, accessed October 14, 2014, at http://www.ngdc.noaa.gov/ mgg/dem/demportal.html.

National Oceanic and Atmospheric Administration, Office of Coastal Survey, 2013, Maintained channels in US waters: National Oceanic and Atmospheric Administration, Office of Coastal Survey, accessed September 9, 2014, at http:// coast.noaa.gov/arcgis/rest/services/MarineCadastre/NavigationAndMarineTransportation/MapServer. [Also available at https://data.noaa.gov/dataset.]

U.S. Army Corps of Engineers, 2014a, Charts download: U.S. Army Corps of Engineers, Inland Electronic Navigational Charts, accessed August 11, 2014a, at http://ec2-54-235-7627.compute-1.amazonaws.com/ienc/web/main/ienc_005. htm.

U.S. Army Corps of Engineers, 2014b, Inland electronic navigational charts (IENC): IENC program overview: U.S. Army Corps of Engineers, Army Geospatial Center, accessed August 8, 2014, at http://www.agc.army.mil/Missions/Echarts.aspx.

Publishing support provided by:

Rolla Publishing Service Center

For more information concerning this publication, contact:

Director, USGS National Geospatial Technical Operations Center 1400 Independence Road

Rolla, M0 65401

(573) 308-3500

Or visit the National Geospatial Technical Operations Center Web site at: http://ngtoc.usgs.gov/ 



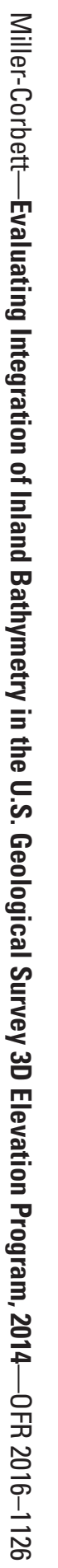

